\title{
ReceiveWHC-EB-Dk73
}

DEC 081989

\section{History of 100-B Area}

\section{DO NOI NIILTURLILI}

Prepared for the U.S. Department of Energy

Assistant Secretary for Management and Administration

\section{Westinghouse \\ Hanford Company Richland, Washington}

Hanford Operations and Engineering Contractor for the

U.S. Department of Energy under Contract DE-AC06-87RL10930 


\section{DISCLAIMER}

This report was prepared as an account of work sponsored by an agency of the United States Government. Neither the

United States Government nor any agency thereof, nor any of their employees, nor any of their contractors, subcontractors or their employees, makes any warranty, expressed or implied, or assumes any legal liability or responsibility for the accuracy, completeness, or any third party's use or the results of such use of any information, apparatus, product, or process disclosed, or represents that its use would not infringe privately owned rights. Reference herein to any specific commercial product, process, or service by trade name, trademark, manufacturer, or otherwise, does not necessarily constitute or imply its endorsement, recommendation, or favoring by the United States Government or any agency thereof or its contractors or subcontractors. The views ano opinions of authors expressed herein do not necessarily state or reflect those of the United States Government or any agency thereof

\section{Available from}

U.S. Department of Commerce

National Technical Information Service

5285 Port Royal Road

Springfield, VA 22161

NTIS Price Codes:

Microtiche Copy: A01

Printed Copy

$\begin{array}{llll}\text { Pages } & \begin{array}{l}\text { Price } \\ \text { Codes }\end{array} & \text { Pages } & \begin{array}{l}\text { Price } \\ \text { Code }\end{array} \\ 001-025 & \text { A02 } & 301-325 & \text { A14 } \\ 026-050 & \text { A03 } & 326-350 & \text { A15 } \\ 051-075 & \text { A04 } & 351-375 & \text { A16 } \\ 076-100 & \text { A05 } & 376-400 & \text { A17 } \\ 101-125 & \text { A06 } & 401-425 & \text { A18 } \\ 126-150 & \text { A07 } & 426-450 & \text { A19 } \\ 151-175 & \text { A0B } & 451-475 & \text { A20 } \\ 176-200 & \text { A09 } & 476-500 & \text { A21 } \\ 201-225 & \text { A10 } & 501-525 & \text { A22 } \\ 226-250 & \text { A11 } & 526-550 & \text { A23 } \\ 251-275 & \text { A12 } & 551-575 & \text { A24 } \\ 276-300 & \text { A13 } & 576-600 & \text { A25 } \\ & & & \end{array}$

Printed in the United States of America 


\section{DISCLAIMER}

This report was prepared as an account of work sponsored by an agency of the United States Government. Neither the United States Government nor any agency Thereof, nor any of their employees, makes any warranty, express or implied, or assumes any legal liability or responsibility for the accuracy, completeness, or usefulness of any information, apparatus, product, or process disclosed, or represents that its use would not infringe privately owned rights. Reference herein to any specific commercial product, process, or service by trade name, trademark, manufacturer, or otherwise does not necessarily constitute or imply its endorsement, recommendation, or favoring by the United States Government or any agency thereof. The views and opinions of authors expressed herein do not necessarily state or reflect those of the United States Government or any agency thereof. 


\section{DISCLAIMER}

Portions of this document may be illegible in electronic image products. Images are produced from the best available original document. 


\section{History of 100-B Area}

R. K. Wahlen

Date Published

October 1989

Prepared for the U.S. Department of Energy

Assistant Secretary for Management and Administration

(20)

Westinghouse

P.O. Box 1970

Hanford Company Richland, Washington 99352

Hanford Operations and Engineering Contractor for the

U.S. Department of Energy under Contract DE-AC06-87AL10930 
WHC-EP-0273

This page intentionally left blank.

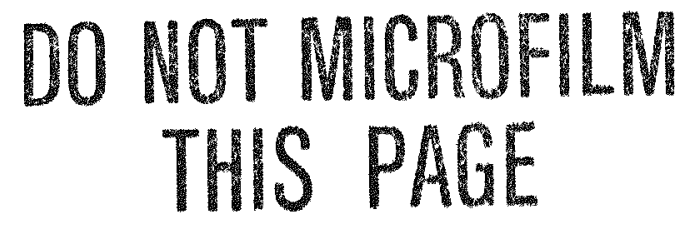


WHC-EP-0273

\section{EXECUTIVE SUMMARY}

In August 1939, Albert Einstein wrote a letter to President Roosevelt that informed him of the work that had been done by Enrico Fermi and L. Szilard on converting energy from the element uranium. He also informed President Roosevelt that there was strong evidence that the Germans were also working on this same development.

This letter initiated a program by the United States to develop an atomic bomb. The U.S. Army Corps of Engineers, under the Department of Defense, was assigned the task. The program, which involved several locations in the United States, was given the code name, Manhattan Project. E. I. du Pont de Nemours \& Company (Du Pont) was contracted to build and operate the reactors and chemical separations plants for the production of plutonium.

On December 14, 1942, officials of Du Pont met in Wilmington, Delaware, to develop a set of criteria for the selection of a site for the reactors and separations plants. The basic criteria specified four requirements: (1) a large supply of clean water, (2) a large supply of electricity, (3) a large area with low population density, and (4) an area that would cover at least 12 by $16 \mathrm{mi}$.

On December 16, 1942, a team left Washington D.C., to investigate sites in the west. On January 2, 1943, the site report was filed and the Hanford Site was selected as the central location for the plant and was given the name Hanford Engineer Works.

The site was located in the Hanford/White Bluff area in south central Washington State along the Columbia River. Figure $i$ shows the geographical location of the Hanford Site. The original installation included construction of the following facilities:

- A construction camp to support 40,000 construction workers with barracks, 3,563 trailer sites, mess halls, post office, theater, recreation halls, and hospital

- A village with grocery stores, dormitories, hotel, hospital, cafeteria, movie theaters, gas stations, clothing store, department store, single and multiple dwellings for about 5,000 families, and related utilities to house the operating personnel and their families

- A nuclear fuels production plant with support facilities

- Three nuclear reactors with support facilities spaced several miles apart 
- An interim storage facility for irradiated fuel

- Three plutonium separations plants located in two different areas, each area containing its own support facilities.

Construction started in March 1943 and was completed in March 1945. Since the processes of producing the end product were new and unproven, it was desirable to test all processes as early in the construction phase as possible in the event that changes would be necessary. To this end, in January 1945, the entire process for manufacturing plutonium had been proved from raw uranium ore to the finished product.

B Reactor produced the first plutonium for the first atomic bomb tested at Trinity Site, New Mexico, and for the bomb exploded over Nagasaki, Japan, bringing about the end of World War II.

The tritium used in the first hydrogen bomb tested at the Pacific Proving Grounds on October 31,1952 , was also produced at 100-B.

The combined operating life of the three original reactors constructed on the Hanford Engineering Works project was $62 \mathrm{yr}$, with deactivation of $100-F$ on June 25, 1965, 100-D on June 26, 1967, and 100-B on February 12, 1968.

In September 1976, the American Society of Mechanical Engineers (ASME) established B Reactor as a National Historic Mechanical Engineering landmark. This award honored those engineers who were directly responsible for locating and obtaining the necessary land, materials, and workforce required to complete the construction of the B Reactor. The logistics and engineering demanded by the project were staggering. The inscription on the award is as follows: "This nuclear reactor was the first to demonstrate the practicality of producing large quantities of plutonium and was a major milestone in the U.S. Atomic Energy program." 


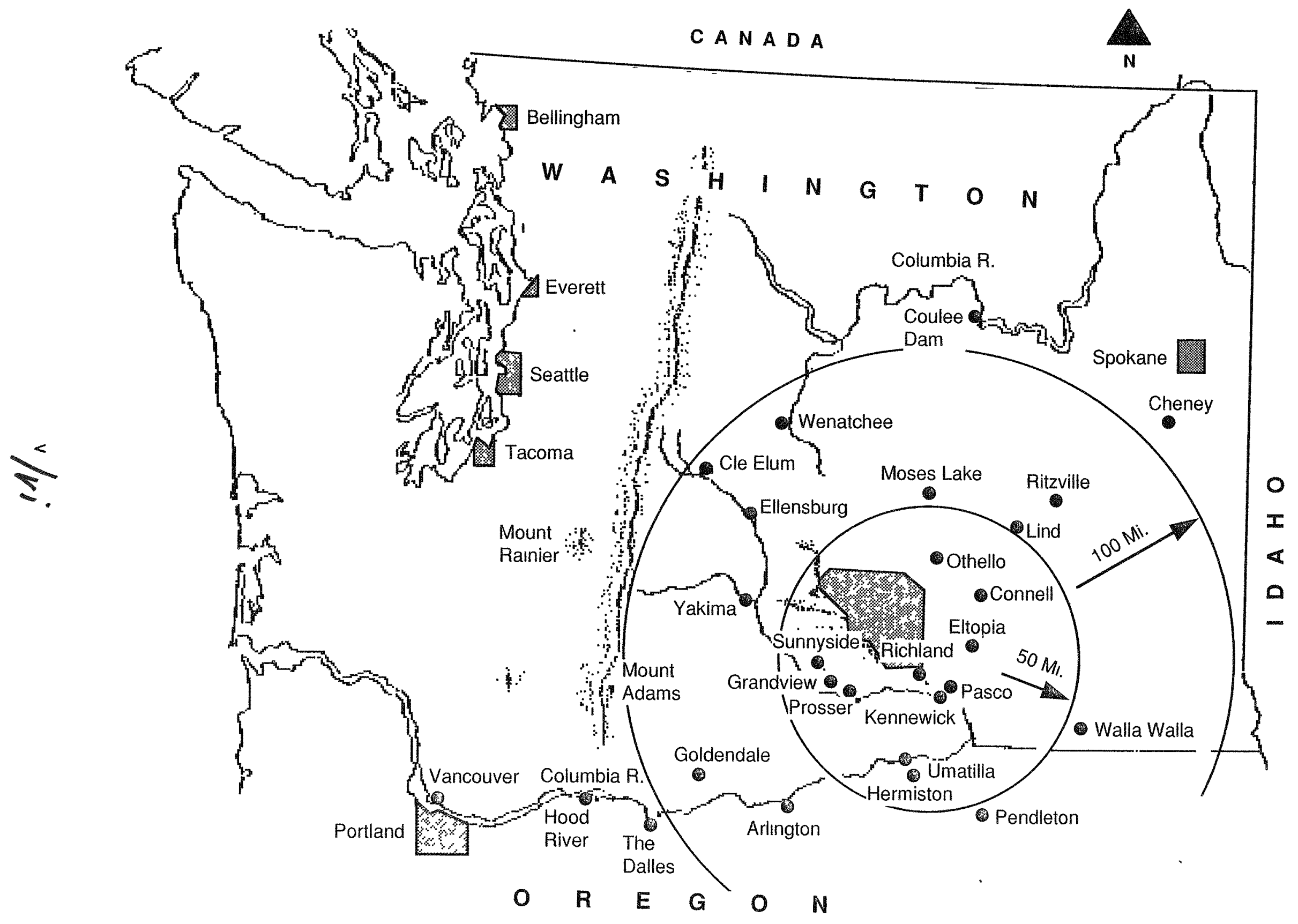

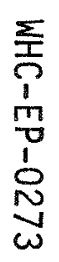

Figure i. Hanford Site Location. 
WHC-EP-0273

This page intentionally left blank.

\section{DO NOT MICROFLLM THIS PAGE}


WHC-EP-0273

\section{CONTENTS}

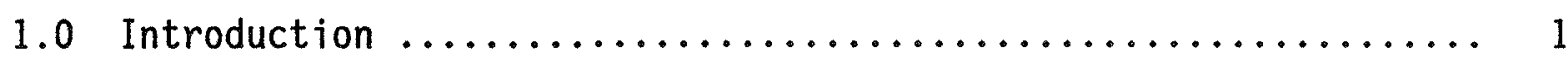

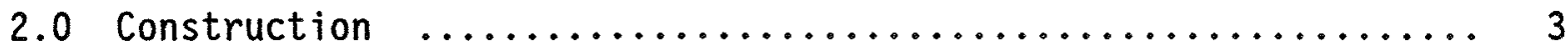

3.0 Reactor and Support Facilities Description $\ldots \ldots \ldots \ldots \ldots$

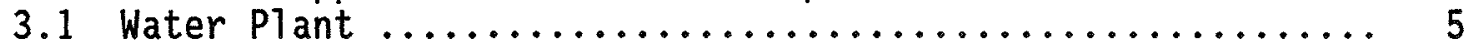

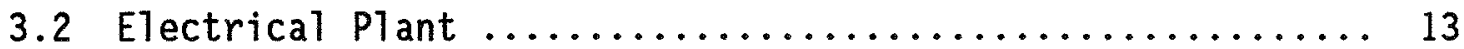

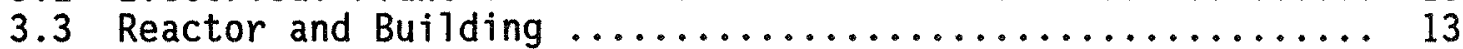

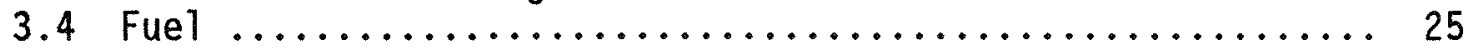

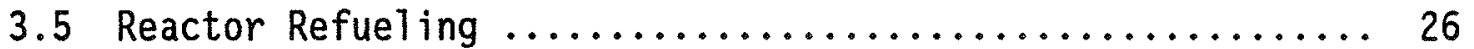

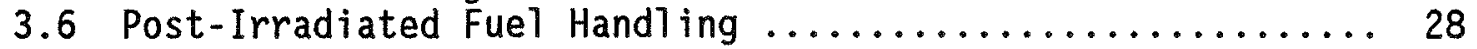

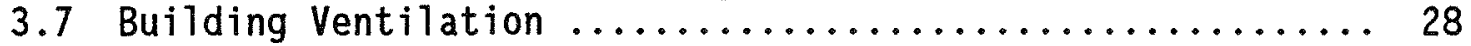

3.8 Office and Service Buildings ..................... 29

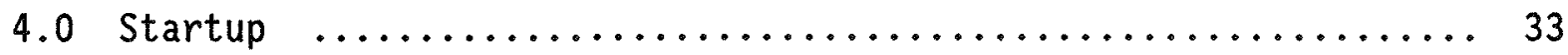

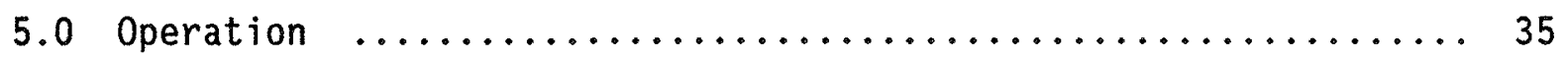

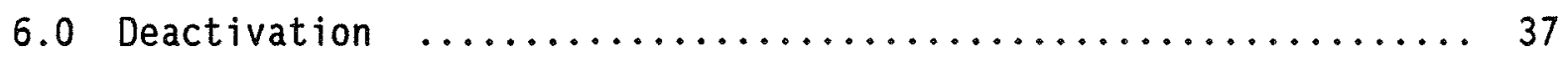

Appendices:

A. Pictorial Review of Construction $\ldots \ldots \ldots \ldots \ldots \ldots \ldots$. 


\section{LIST OF FIGURES}

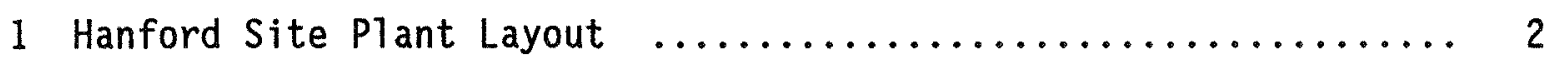

2 Diagram of Primary Coolant Flow ........................ 6

3 Sequence of 183 Water Treatment Operation $\ldots \ldots \ldots \ldots \ldots \ldots$.

4 Primary Pump and Drive Assembly $\ldots \ldots \ldots \ldots \ldots \ldots \ldots \ldots \ldots \ldots \ldots$

5 100-B Area Steam Distribution Grid $\ldots \ldots \ldots \ldots \ldots \ldots \ldots \ldots \ldots \ldots \ldots \ldots$

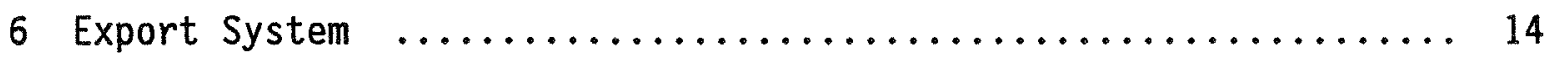

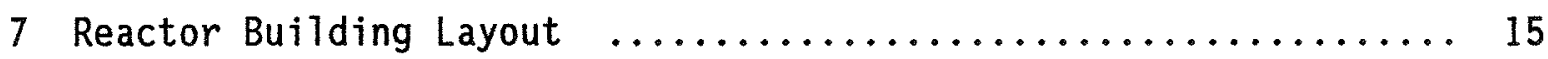

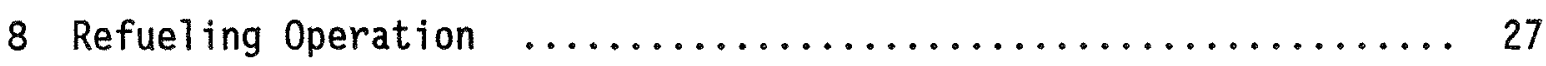


WHC-EP-0273

\section{HISTORY OF 100-B AREA}

\subsection{INTRODUCTION}

The initial three production reactors and their support facilities were designated as the 100-B, 100-D, and 100-F Areas. In subsequent years, six additional plutonium-producing reactors were constructed and operated at the Hanford Site. Among them was one dual-purpose reactor (100-N) designed to supply steam for the production of electricity as a by-product. Figure 1 pinpoints the location of each of the nine Hanford Site reactors along the Columbia River. This report documents a brief description of the 105-B Reactor, support facilities, and significant events that are considered to be of historical interest. 


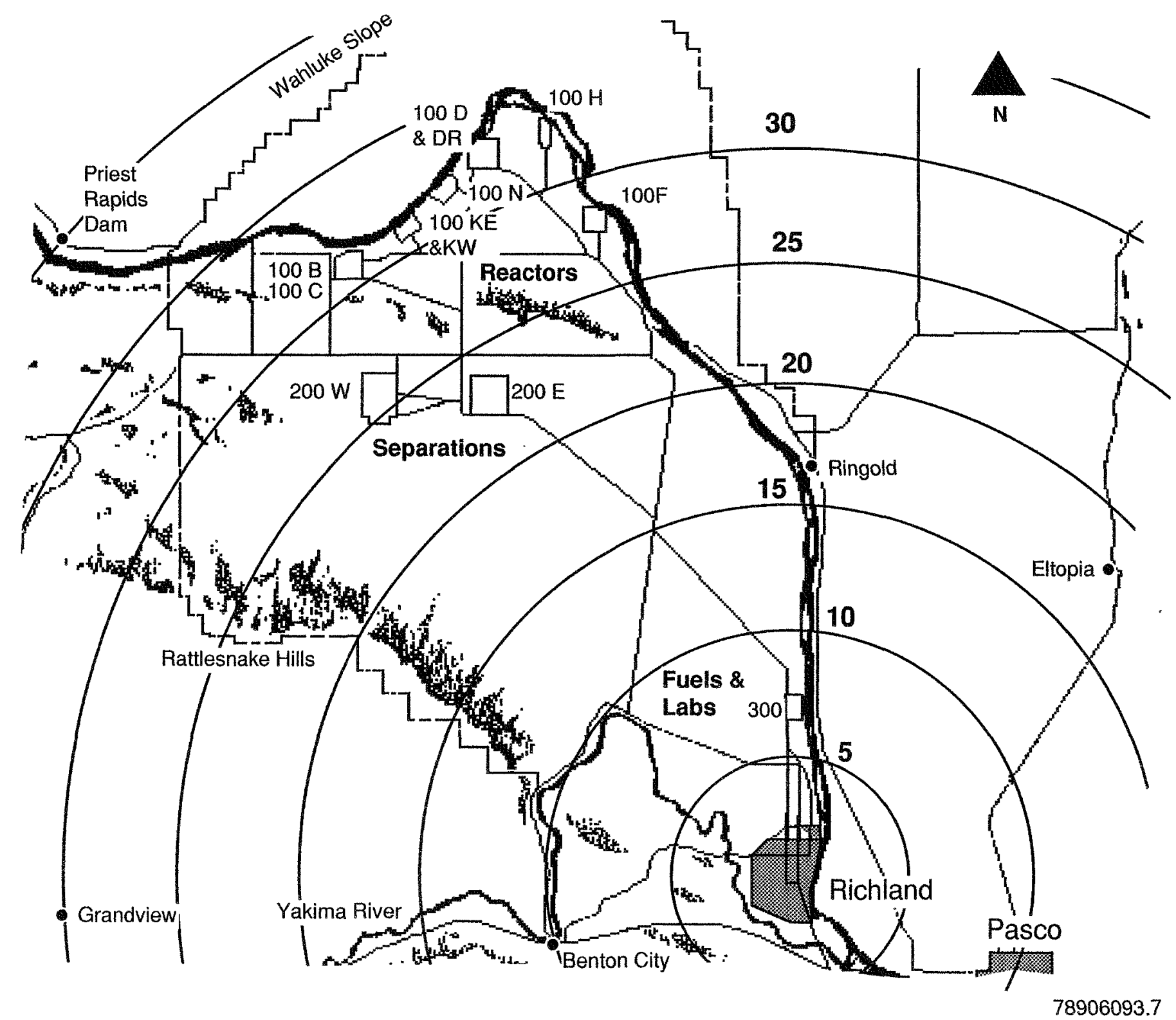

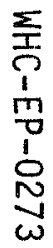

Figure 1. Hanford Site Plant Layout. 


\subsection{CONSTRUCTION}

Construction started on the 100-B Area in August 1943 and was completed and turned over to operations on September 13, 1944. Starting in June 1944, operating crews were assigned to follow acceptance tests on specific systems as construction progressed.

In June 1951, construction started on a second reactor in the 100-B Area. The new reactor was identified as the $C$ Reactor and support facilities. Systems and Operation processes of $C$ Reactor will be presented in a separate section of the History of the 100 Areas.

The reliability and safety that were designed and constructed in an unproven process, coupled with 100-B being built on a critical, restrictive time schedule and as a part of the largest construction project undertaken in U.S. history, are, in themselves, historical. There has never been a greater demand on manpower in the history of the United States than during the construction phase of the Hanford Site. The desired construction manpower level was never achieved; however, all facilities were completed on or ahead of schedule.

Appendix A contains photographs taken during construction. 
WHC-EP-0273

This page intentionally left blank.

\section{DO NOT MICROFILM THIS PAGE}


WHC-EP-0273

\subsection{REACTOR AND SUPPORT FACILITIES DESCRIPTION}

\subsection{WATER PLANT}

The water plant design was state-of-the-art, and, aside from the large size and reliability of the plant, was not exceptional. The system was capable of producing enough drinking-quality water equivalent to the needs of about 300,000 people. In the design of the primary system and its support systems, every conceivable interruption was considered to ensure the highest degree of reliability in supplying cooling flow to the reactor.

Approximately $94 \%$ of the heat produced in a reactor is generated in the uranium fuel and the remainder in the graphite moderator. The rate of removal of the heat is critical to the safe operation of a reactor. An adequate continuous supply of cooling water was needed to avoid a fuel meltdown and the consequential release of fission products.

Three systems were available to provide an adequate flow of coolant for the reactor. They were an electrically-powered pumping system designated as the primary coolant system, a steam-powered pumping system designated as the secondary coolant system, and a dual system of elevated water tanks and a pipeline interconnecting all the reactor plants designated as the last ditch system.

\subsubsection{Primary Coolant System}

The primary coolant system provided adequate reactor cooling during all phases of operation and shutdown. The systems were designed so that they did not require any help from either of the other two systems to provide the required amount of coolant. Electrical power was the energy source for this system. The sequence of operation is shown schematically in

Figure 2.

3.1.1.1 River Pump House--181 Building. Cooling water for the reactor was drawn from the Columbia River by means of pumps located in the river pump house known as the "181 Building." All pumps were vertical deep-well type with submerged bowls and impellers. The water intake channel in front of the 181 Building was dredged and lined with rock and concrete to form the forebay. There were 10 electric-driven pumps with a capacity of $10,500 \mathrm{gal} / \mathrm{min}$ at $180-\mathrm{ft}$ head. Two were powered by 450 -hp motors and 8 by 600-hp motors.

3.1.1.2 Reservoir and Pump House--182 Building. The purpose of the reservoir and pump house was to provide reserve water for reactor cooling, condenser water for the steam condensers, and raw water for the Separations Plants (200 Areas). The 182 Building contained an inlet house, an open concrete reservoir, and a pump room. The reservoir capacity was

$25,000,000$ gal. There were seven pumps in the pump room, each capable of pumping $6,000 \mathrm{gal} / \mathrm{min}$. 


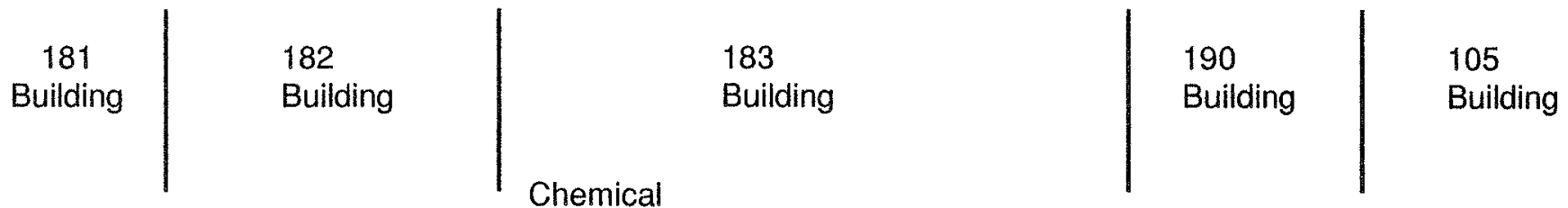

Addition

Building

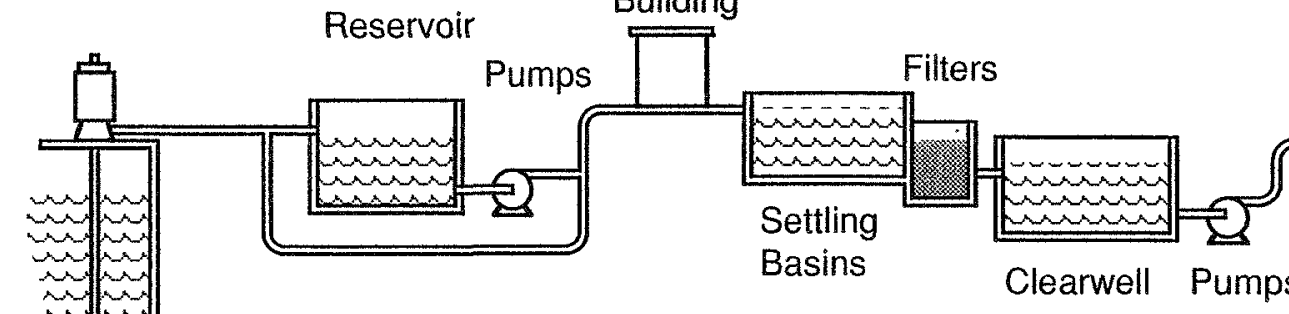

4 Storage Tanks

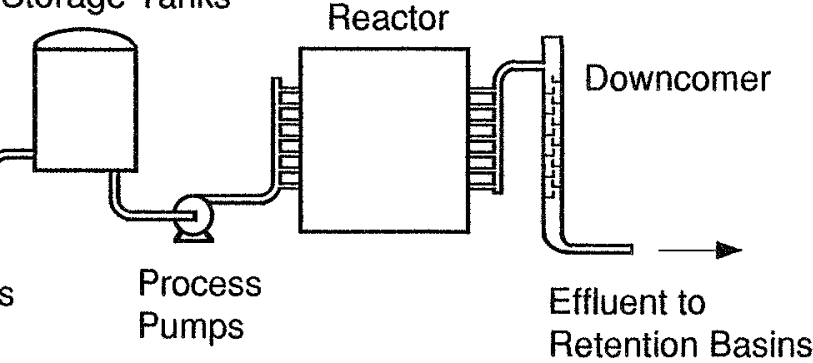

좀
I
m
d
d
$\omega$

78906093.3

Figure 2. Diagram of Primary Coolant Flow. 
WHC -EP-0273

Before plant modifications were performed in 1956 to 1957 under Project CG-558, the reservoir was used as the principal water supply source for the filter plant. Following Project CG-558, cooling water was supplied directly from the river pumps to the filter plant; however, the 182 Facility still played an important part in the reactor plant cooling system because it was the main source of "export water" used for emergency cooling.

3.1.1.3 Filter Plant and Chemical Treatment--183 Building. Although Columbia River water is unusually clean and pure, it must be filtered and chemically treated to prevent filming in the reactor process tubes. This is the purpose of the 183 Building and its components. The 183 Filter Plant consisted of a head house, raw water flume, mixing chambers, distribution flume, flocculators, settling basins, collection flume, filters, effluent and backwash piping, effluent flumes, and clearwells. Figure 3 illustrates the sequence of operation.

The basins, filters, flumes, clearwells, and buildings were reinforced concrete. The construction of the walls of the head house and filter building was concrete block.

- Head House--River water entered the filter plant through two 36-in. carbon steel pipe lines. Alum, sulfuric acid, and chlorine were proportioned in the head house and added to the raw water. The alum was used as a flocculating agent and the sulfuric acid was used to control the acidity of the water as well as to produce the alum. Chlorine was also added at this point for algae control in the settling basins.

- Mixing Chamber--There were two mixing chambers in each half of the filter plant. Raw water flows through the raw water flume into the distribution flume and into the mixing chambers. The purpose of the mixing chambers was to mix the chemicals with the water.

- Flocculators and Settling Basins--The flocculators and settling basins were open to the atmosphere. There were two paddle-wheel flocculators in series for each of the 12 settling basins. The purpose of the settling basins was to allow heavier particulate matter to settle out of the water before entering the filters.

- Filters--All filters were gravity-flow type and equipped with Wheeler bottoms. (A Wheeler bottom is a matrix of inverted cones with a ceramic ball in each cone.) Each filter consisted of two halves with a gullet between them. The filter media consisted of about 12-in. of grave1, 20-in. of sand, and 10-in. of crushed anthracite coal. The total surface area of all the filters was $13,824 \mathrm{ft}^{2}$. Water entered the gullet from the influent flume and flowed to both halves of the filter through port openings. 
Head House \& Chemical Addition Bldg.

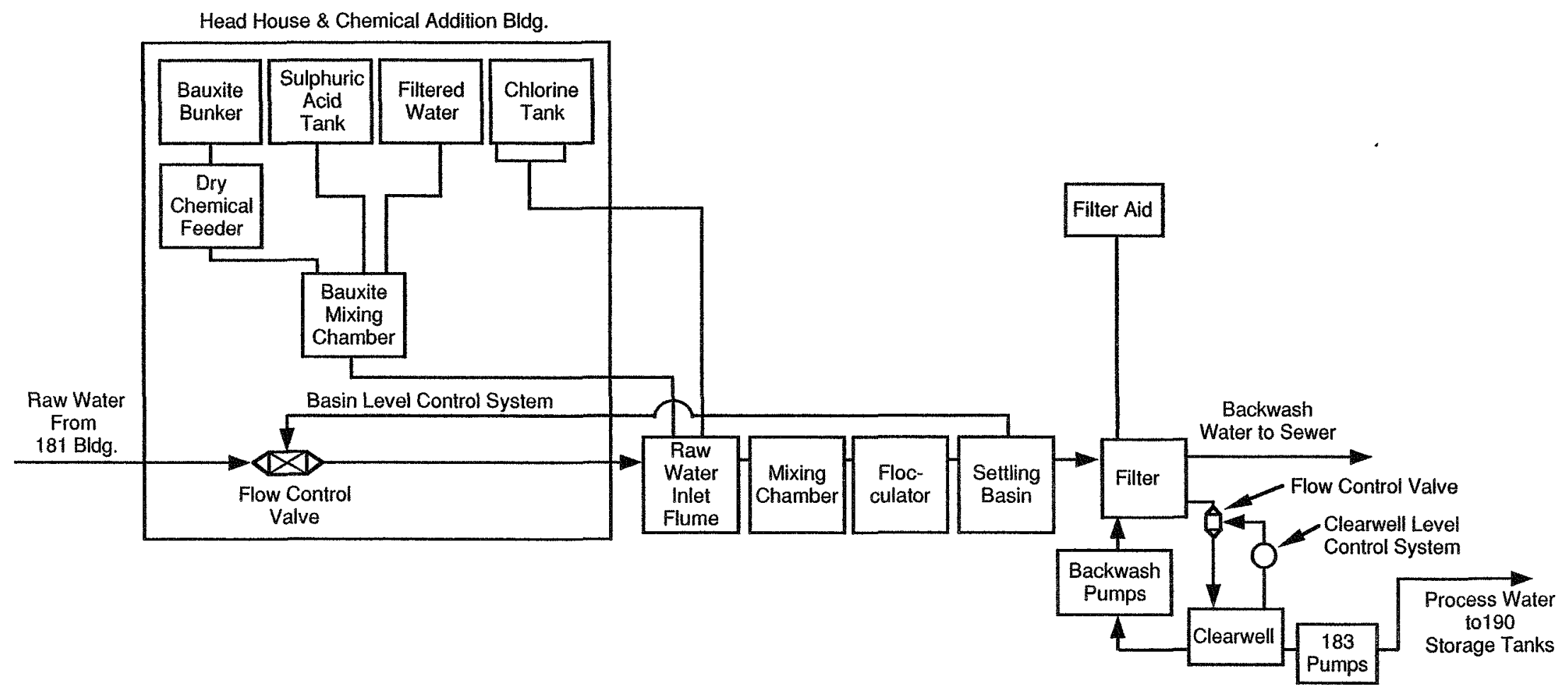

Figure 3. Sequence of 183 Water Treatment Operation. 
WHC-EP-0273

An organic polyelectrolyte filter aid was added to the water in the gullet to improve water quality by improving filter efficiency. The filtered water collected in the false bottom below the filter and flowed through the effluent piping to the effluent flume and then through effluent piping to the clearwells.

Water for filter backwashing was supplied from the clearwells by backwash pumps located in the pump room of the 183 Building. Backwash water entered the false bottom under the filter, flowed upward through the filter media into the gullet, and out through a waste valve into the sewer.

- Clearwe17s--The underground clearwe11s, which were constructed of reinforced concrete, were covered by a flat slab concrete roof supported by concrete columns spaced approximately $20 \mathrm{ft}$ apart. There were two clearwells separated by a pump room. Each clearwell had a suction well adjacent to the pump room and was connected to the others by a flume with a sluice gate at each end of the flume. The total storage capacity of the two clearwells was $10,000,000 \mathrm{gal}$.

- Pump Room--The 183 pump room was the primary supply point for filtered water for the entire production plant. Pumps were provided to transfer primary reactor coolant to the 190 storage tanks, to provide backwash water for the filters, to provide water to the high tanks at the reactor, to provide water for steam generation at the power house, to provide fire and sanitary water, and for emergency filtered water. The total capacity of the 183 pumping facility was $116,000 \mathrm{gal} / \mathrm{min}$.

\subsubsection{190 Building and Pump Annex.}

- Water Storage Tanks--190 Building--Four large steel storage tanks were provided at the 190 Building to supply water to the primary coolant pumps for the reactor. A corrosion inhibitor, sodium dichromate, was added at the 36-in. inlet to each end of the distribution header that supplied each tank through an individual line from the header to each tank.

Each tank had a storage capacity of $1,750,000$ gal. The tank discharge pipe lines tied into a common header that supplied the primary coolant pumps.

- Primary Coolant Pumps--Originally there were 12 steam turbine pumps that pumped the process water from the storage tanks and supplied a positive head to 12 electric high-lift pumps. The high-lift pumps in turn supplied the process water to risers on the front of $B$ Reactor. The risers were connected to the individual process tubes through crossheaders and individual tube connectors. Following Project CG-558 in 1956, which increased the coolant flow capabilities to the reactor from approximately $30,000 \mathrm{gal} / \mathrm{min}$ to $70,000 \mathrm{gal} / \mathrm{min}$, the 190 Building pumps were used for emergency backup. 
WHC-EP-0273

The post-CG-558 primary coolant was supplied from eight electrically-driven, two-stage, horizontal centrifugal pumps located in a newly constructed 190 Annex. The pump and drive assembly were composed of a 4,500-hp synchronous motor and a direct connected exciter, a 20-ton flywheel to slow the rate of decay in flow in the event of a power failure, a 1 to 2.618 speed increasing gear set, two flexible couplings, and a two-stage centrifugal pump. Figure 4 illustrates this assembly.

\subsubsection{Secondary Coolant System}

Total failure of electric power to the Hanford Site was considered a possibility. In such an event, a secondary power source was available. It was independent of the electrical or primary source and was capable of providing adequate cooling water to the reactor until the primary system could be reestablished. It was not intended to duplicate the capabilities of the primary cooling system, but was regarded as a means of preventing damage to the reactor.

A steam plant, the 184-B Power House, was provided to supply power to steam turbines for driving the secondary cooling system. There were four boilers in 184-B, each capable of rapid accelerations to produce $100,000 \mathrm{lb} / \mathrm{h}$ of steam at $225 \mathrm{ib} / \mathrm{in}^{2}$ (gage) and $450{ }^{\circ} \mathrm{F}$, and could produce $135,000 \mathrm{ib} / \mathrm{h}$ of steam for short periods of time. The steam distribution system in the 100-B Area was supplied in overhead lines as shown in Figure 5.

The secondary coolant system components at the 181 river pump house were two steam-turbine vertical pumps, each capable of pumping $15,000 \mathrm{gal} / \mathrm{min}$ to the 182 reservoirs or the $183 \mathrm{Fi}$ ter $\mathrm{Plant}$. The $183 \mathrm{Filter} \mathrm{Plant}$ pump house contained three steam-driven pumps capable of delivering $12,000 \mathrm{gal} / \mathrm{min}$ to the four 190 storage tanks.

The most important link in the secondary coolant system was the 12 steam turbine pumps that pumped water to the reactor from the 190 pump room. These pumps were also used as an operating convenience to supply cooling water to the reactor during normal reactor outages.

\subsubsection{Last Ditch System}

The last ditch system was designed to provide adequate cooling water to meet the reactor shutdown requirements indefinitely. This was done by providing two major components in the system: the reactor high tanks and the export water system. The reactor had two 300,000-gal high tanks which, by the use of check valves, automatically supplied water whenever the line pressure to the reactor fell below the static head pressure of the tanks. The flow was adequate to satisfy the cooling requirements of the reactor during the 


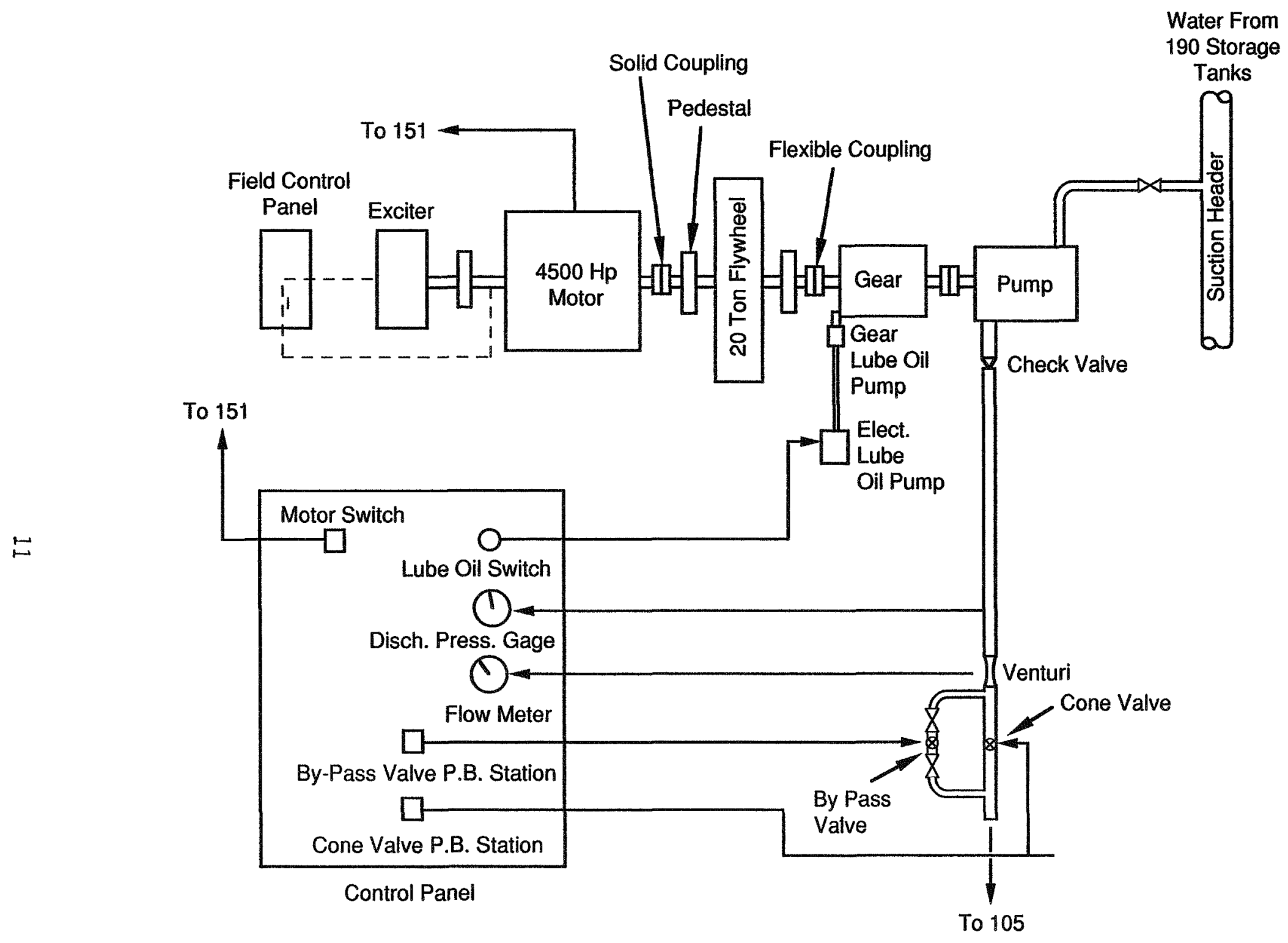

Figure 4. Primary Pump and Drive Assembly. 


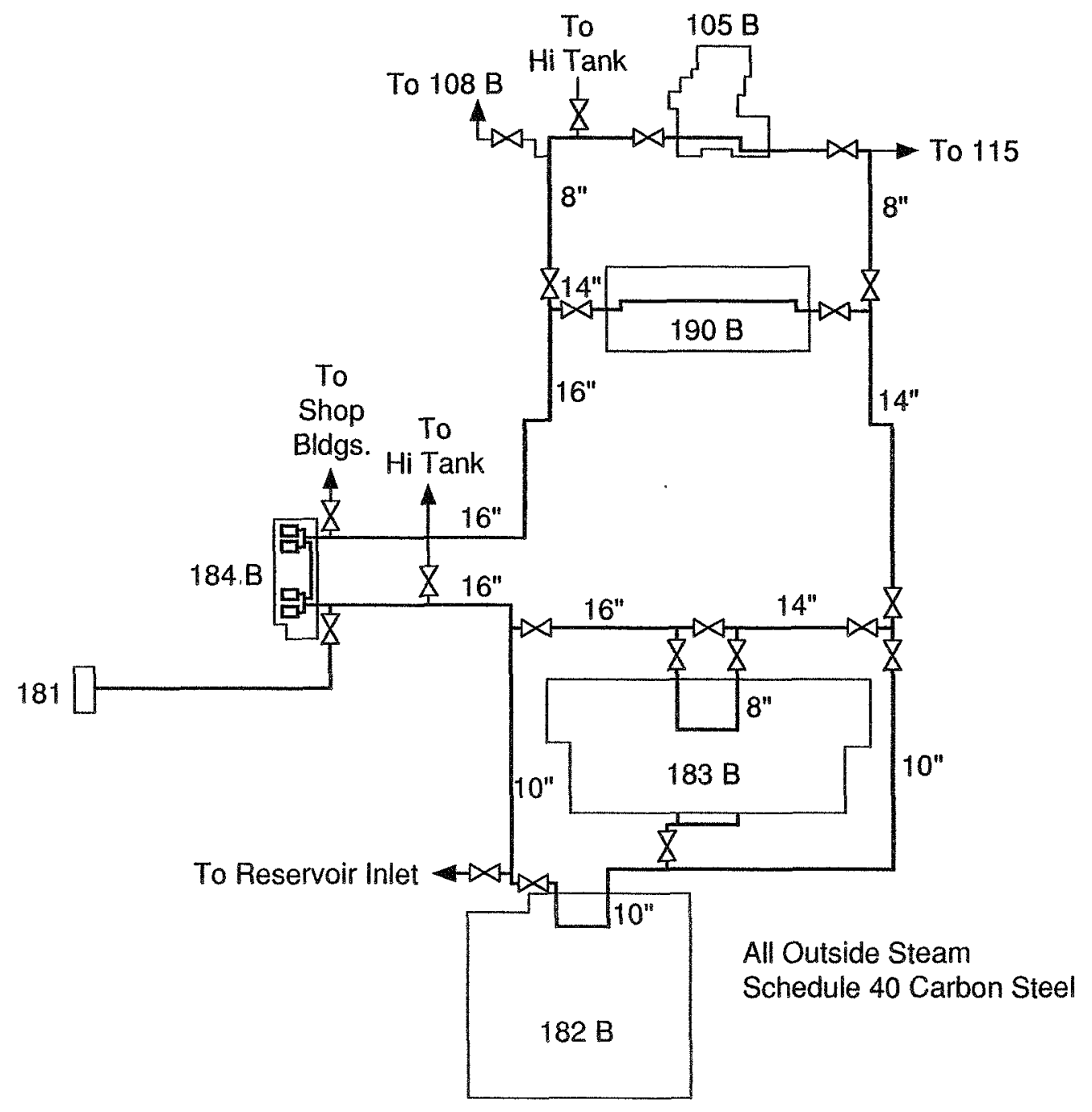

78906093.2

Figure 5, 100-B Area Steam Distribution Grid. 


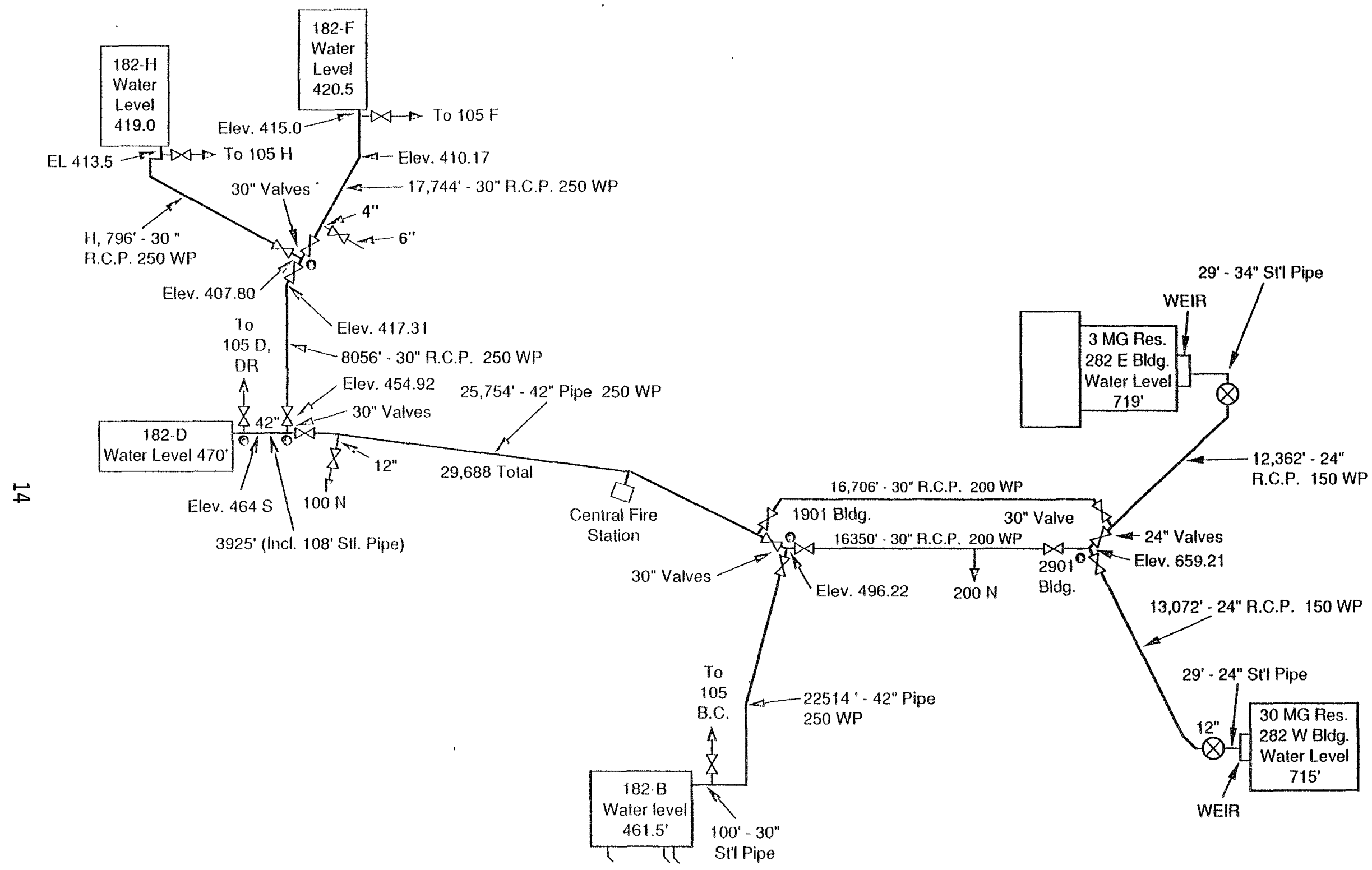

Figure 6. Export System. 


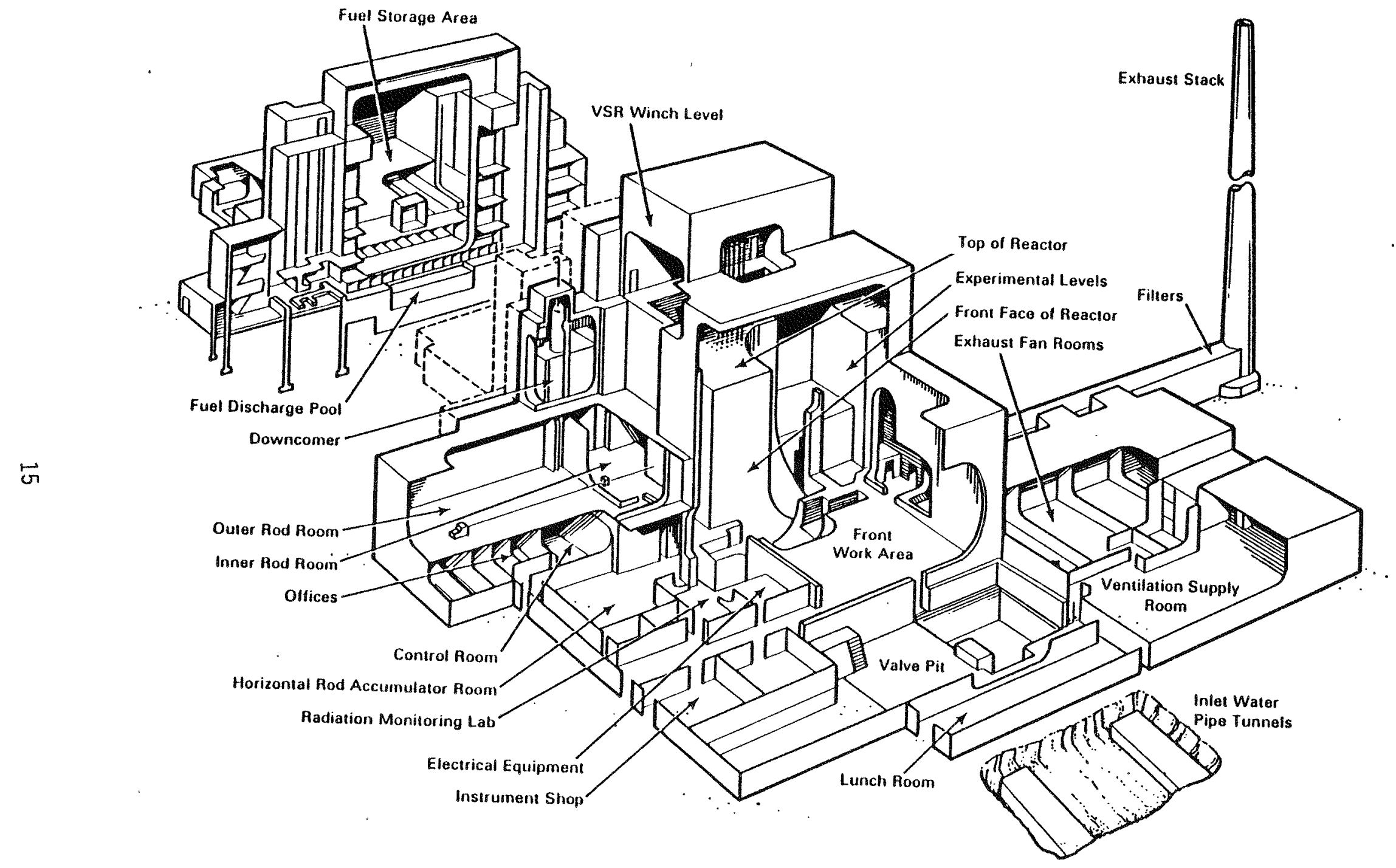

종
i
m
!
d
w

Figure 7. Reactor Building Layout. 
The charging face, or front face, of the reactor block faced the 190 cooling water pump room. Two underground reinforced-concrete tunnels connected the two buildings and served as the pipe run for the reactor cooling water. Nine horizontal control rods entered the left side of the reactor, when facing the front of the reactor. The control room was also located on the left side of the reactor. Experimental test holes provided in the reactor block were serviced on the right side of the reactor. The fuel discharge area and irradiated fuel storage area were located behind the reactor outlet face (rear face) and were interconnected by an underwater chute. The building extends about $50 \mathrm{ft}$ above the top of the reactor to provide for the operation of the 29 vertical safety rods which enter from the top of the reactor.

\subsubsection{Reactor Components}

3.3.1.1 Graphite Moderator Stack. The overall nominal dimensions of the graphite stack are front to rear, $28 \mathrm{ft}$; top to bottom, $36 \mathrm{ft}$; and side to side, $36 \mathrm{ft}$. The stack was made up of graphite blocks $43 / 16-\mathrm{in}^{2}$ by 48-in. long. The graphite blocks were stacked in layers with the long dimension of the blocks parallel within a layer and at right angles to the long dimension of the blocks in the adjacent layers. The bottom graphite layer rested on a carefully leveled surface made up of cast iron blocks which were used as a thermal shield. These, in turn, are laid in grout on top of a massive concrete foundation prepared for the reactor. Alternate blocks in the front to rear layers were pierced for process tubes, giving a total of 2,004 process tubes in the reactor. The graphite blocks were keyed in position to stabilize the block. The corners of both the tube and filler blocks in the tube row layers were beveled to provide passage for the circulating reactor gas atmosphere. One-quarter-inch diameter weep holes on $12-$ in. centers extending to the four corners of the tube channel were provided to expedite removal of moisture that collected as condensate or leaked to the stack from process tube leaks.

In December 1942, scientist E. P. Wigner postulated that fast neutrons in the graphite stack would cause changes in the physical properties of the graphite. It was from his early theories that the term "Wigner's effect" arose. His postulation proved to be true. The graphite stack experienced distortion from unequal growth or contraction of the graphite during irradiation. A typical tube channel vertical traverse showed the graphite in the outer edges of the stack to have expanded while the core contracted. The displacements were as much as 1 to 2 in. expansion and $11 / 2$ to 3 in. contraction. The movement was more pronounced in the side-to-side direction than in the front-to-rear. In the early stages of operation, the "Wigner's effect" prompted the $p l a n n e r s$ to design replacement reactors for $B, D$, and $F$ Reactors. Before it was learned that the growth could be managed, the replacement reactor for $D$ Reactor had progressed to the point where it was decided to construct and implement DR, as an added production facility.

Vertical safety rod channel penetrations extended from the top to the bottom of the stack. There were 29 vertical channels provided for safety rods. 
WHC-EP-0273

3.3.1.2 Reactor Shield. The primary objective in the reactor shielding was to assure operating personnel that exposure to radiation would not exceed long-term tolerance limits. Personnel were assured of this by a combined thermal and biological shield designed by Fermi and Zinn in 1943.

- Thermal Shield--Between the graphite stack and the outer biological shield was a layer of cast iron designated as the thermal shield. The thickness of this shield varied from $8 \mathrm{in}$. at the reactor sides, $81 / 8-i n$. at the top, 10-in. on the front and rear, to $101 / 4-i n$. on the bottom. Approximately $97 \%$ of the gamma energy was absorbed in this shield and converted to heat in the cast iron.

Cooling for the top, bottom, and side shields was provided by circulating water tubes imbedded in the blocks. The front and rear thermal shields were cooled by water flow through the process tubes that passed through the shield.

- Biological Shield--The thermal shield was surrounded on all sides except the bottom by a 52 -in.-thick biological shield made up of alternate layers of masonite and steel. The biological shield absorbed the energy, radiated from the reactor, which passed through the thermal shield. This energy consisted largely of fast neutrons. The neutrons were slowed to intermediate energy in the steel layer and then moderated to thermal energy in the masonite. The entire reactor block was enclosed in a welded steel box that served to confine the gas atmosphere within the reactor. Neoprene expansion joints were provided on the corners of the block for thermal expansion. Expansion bellows were also provided for each process tube penetration. The bellows also served as gas seals.

3.3.1.3 Gas System. The purpose of the gas system was to circulate an inert, nonradioactive gas through the reactor to remove moisture and foreign gases from the reactor, to serve as a heat transfer media between the graphite and process tubes for removal of heat from the graphite, and to detect water leaks within the reactor.

The reactor atmosphere was a mixture of helium and carbon dioxide, with the composition varied and regulated to control graphite temperatures that influenced reactivity conditions and helped control the graphite growth problem.

The apparatus for circulating, drying, and filtering the gas was located in the 115 Building, which was separate from the 105 Reactor Building. Piping was provided through tunnels connecting the 115 Building to the 105 Building. Adjacent to the 115 Building was gas storage and unloading station, identified as the 110 Building.

Helium was received in railroad tank cars and unloaded into highpressure (700 $\mathrm{lb} / \mathrm{in}^{2}$ [gage]) storage tanks. The helium was then transferred to low-pressure tanks (50 to $100 \mathrm{lb} / \mathrm{in}^{2}$ [gage]) for makeup in the gas loop. 
WHC -EP-0273

Carbon dioxide was received by tank trucks and stored in low-pressure tanks for makeup in the gas loop.

The water-leak detection system of the reactor-gas system consisted of 100 sampling tubes spaced evenly on the discharge face of the reactor and located in the gas plenum between the biological and thermal shield. Water from a leak within the reactor flashed to steam and was removed from within the reactor by the flowing gas stream. The detection and approximate location of a leak were determined by measuring the water vapor in the 100 gas sampling tubes. Drip legs were provided in the low points in the loop piping to remove water that condensed from the gas stream. The seriousness of a leak could be determined by the rate water was collected in the drip legs. This water, plus the water collected in the dryer beds following process tube leaks, provided a measured amount of water that entered the graphite stack.

3.3.1.4 Reactor Inlet Piping. In the original design of the reactor, provisions were made to split the flow to what was termed "chilled" and "unchilled" sections of the reactor, the chilled section being the central zone process tubes in the reactor and the fringe being the tubes on the periphery of the central zone. It was theorized that it might be necessary to chill the cooling water flowing to the high production tubes. In actual experience, it was not necessary to chill the cooling flow.

Process cooling water was pumped from the 190 Building through 24-in. pipes to a common header in the 105 Building valve pit. The cooling water from the common header was divided into two 36-in. headers that ran to the reactor. At the base of the reactor, the water flow was directed upward through 36-in. risers on both sides of the reactor face. The water was then distributed across the reactor's front face through 4-in. stainless steel headers, which were connected to the risers on both ends. The 4-in. crossheaders supplied water to the individual process tubes through special connectors identified as "pigtails." (The original connectors were 1/2-in. aluminum tubing formed into an expansion coil which resembled a pig's tail.)

There were 39 crossheaders to supply 46 horizontal rows of tubes. The top and bottom crossheaders supplied a single row of tubes. The next three crossheaders, from those at the top and bottom of the pattern, supplied two rows of tubes each. Alternate crossheaders in the rest of the pattern supplied two rows of tubes in the central zone, or two rows of tubes in the fringe zone, respectively. The configuration was such that if flow was stopped to a process tube, the tube would remain full of water. This was termed "submerged cooling."

Emergency high-tank water was connected to the $36-$ in. supply header to the risers on each side of the reactor. High-tank water was isolated from the 36-in. supply line by a check valve. The export, or last ditch, emergency water was connected from the export system at the common crossheader in the 105 valve pit.

Provisions were made to recirculate hot water, heated with boiler steam, through the reactor to drive out moisture from the graphite in the event of 
an incident that would saturate the graphite with water. This system was not required during the operating history of $\mathrm{B}$ Reactor.

Provisions were also made to inject a slurry of diatomaceous earth into the reactor cooling system to scour the corrosion film from the inner surfaces of the process piping, the process tubes, and the fuel elements, to reduce the friction losses in the system.

3.3.1.5 Reactor Effluent System. The outlet cooling-water piping arrangement on the discharge side (rear face) of the reactor was essentially a duplicate of the inlet piping arrangement. Water from the process tubes flowed from the rear connector (pigtail) to the crossheaders. The crossheaders joined two vertical risers, one on each side of the reactor face. Both risers fed into a common crossover line that discharged into a downcomer. The coolant flow cascaded down baffles in the downcomer pipe into a cement chamber lined with 2-in.-by-10-in. cypress planks. The effluent then flowed by gravity through a 66-in. underground pipeline to the 107 retention basin. The effluent discharged from the 107 basin by gravity to a $60-i n$. Iine and fed into a 1904 water box located on the bank of the Columbia River. A 60-in. line transported the effluent from 1904 to the middle of the river where it was discharged at the bottom of the river.

\subsubsection{Reactivity Control}

Reactivity control was maintained by horizontal control rods (HCR), vertical safety rods (VSR), the $3 X$ safety system, and supplementary control in the form of the Poison Column Control Facility (PCCF) or poison splines. The HCRs, PCCF, and splines provided the necessary control capability and flexibility during normal transient and equilibrium reactor operation. The VSRs provided the necessary control capability to maintain the wet (watercooled) reactor subcritical even after complete xenon decay and to effect a rapid shutdown. The $3 X$ system was designed to provide an independent safety control system with adequate capacity to hold the reactor subcritical under the most limiting conditions, including water loss with the reactor xenonfree.

3.3.2.1 Horizontal Control Rods. The HCR system had two primary functions: to control the reactor power level during routine operation, both equilibrium and transient; and to maintain a balanced and steady neutron flux distribution.

There were nine horizontal control rods. The poison (neutron absorbing) portion or tip section was $29 \mathrm{ft} 41 / 2-i n$. in length. The rod poison and cooling components were made of aluminum tubing, pressed and sintered rings of boron-carbide, and aluminum. The tubing transported 10 gal of cooling water per minute through each rod. Around each of the three tubes were fitted boron-carbide rings. The tubing and rings were contained in an aluminum casing. The portion of the HCR entering the reactor was about $36-\mathrm{ft}$ long attached to a $39-\mathrm{ft}$ section of rod that served as a tooth rack for a driving pinion. Two of the rods were electrically driven and not connected to the scram (automatic shutdown) circuit. The other seven rods, known as "shim 
rods," were designed primarily for course control of the reactor. These rods were driven by hydraulic motors. Emergency-driven power to the shim rods was supplied by three hydraulic accumulators that were gravity-operated and capable of driving the rods in at a speed of up to $30 \mathrm{in} / \mathrm{s}$.

3.3.2.2 Vertical Safety Rods. The VSR system was designed so that failure or malfunction of any single rod or group of rods would not interfere with the operation of the remainder of the system. Each of the 29 VSRs was withdrawn by two cables wound on a winch $40 \mathrm{ft}$ above the top of the reactor. The rod was inserted by reverse action of the winch or, in case of a scram, by gravity drop. An electromagnetic clutch held the rod in the out position. On a scram the magnet was deenergized, releasing the rod and allowing the rod to free fall into the reactor.

Because the VSRs were not in the active portion of the reactor during operation, no cooling system was required for the VSRs. The rods were 39-ft long, stainless steel tubes with a $3 / 16$-in.-thick 1.5 to $2.0 \%$ boron stainless steel sleeve inside. The outside diameter of the rod was $21 / 4 \mathrm{in}$.

3.3.2.3 3X Safety System. In recognition of the possibility of physical shifting of the reactor stack or other damage that could render the safety and control rods useless, a third safety system was designed and installed. The initial system consisted of a tank filled with a liquid boron solution that sat on a pedestal about $5 \mathrm{ft}$ above the top of the reactor. The tank was connected to each of the 29 VSR channels with a $1 / 2-i n$. pipe. The VSR channels were lined with aluminum thimbles designed to contain the boron solution, so it could not be dispersed to the graphite stack. After a short time of operation, 4 to $5 \mathrm{yr}$, the thimbles corroded and started to leak, which meant that if it were necessary to use the boron solution or if it were discharged to the reactor inadvertently, the boron could leak into the graphite and render the reactor permanently inoperable. Consequently, a Ball 3X System was designed and installed in 1953.

Installation of the $B a 113 X$ System required removal of the aluminum thimbles and installation of a ball hopper (container) at the top of each VSR channe1. The hopper and step-plug assembly were designed to funnel 3/8- to 7/16-in. nickel-plated boron steel balls, blended with nickel-plated carbon steel, and stainless steel balls into the VSR channel when required. The system could be tripped manually from the reactor control room or automatically upon rapid loss of cooling water pressure.

Ball removal was accomplished by use of a vacuum system that, through the use of long vacuum tubes, lifted the balls from the individual channels.

3.3.2.4 Supplementary Control. Supplementary control was accomplished by the use of PCCF and poison splines. These control features were not considered or depended on as a reactor shutdown device. The PCCF permitted the charging or discharging of neutron-absorbing material into and out of the reactor during operation. This system consisted of an individual remotely operated pressure control system coupled with ball valves on the outlet end of selected tubes. Manually operated ball valves were installed at the 
WHC -EP-0273

inlet end of the same tubes. A special purpose charging machine was used with these tubes to allow charging of poison during operation.

Development and use of the PCCF system eliminated the need to shut the reactor down for a "poison discharge" following each startup. It al so reduced the amount of downtime required to implement a startup with temporary poison in the reactor. The PCCF system required that 17 tubes be taken out of production and dedicated to the PCCF. As a result, the spline system was developed which permitted inserting a spline (tape) of aluminum sintered with boron-carbide through a special process tube cap and under the fue 1 column. As Operations became more proficient with the spline system, the PCCF system was gradually phased out when the B Reactor was shut down and declared excess.

\subsubsection{Reactor Instrumentation}

There were three basic classifications of instrumentation within the reactor building.

3.3.3.1 Reactor Safety Circuit Instrumentation. Instruments in this classification provided information on status of the process by visual readout devices and were connected directly to the reactor safety circuits for shutdown, if established limits were exceeded.

On the initial startup, there were three circuits which would initiate a scram (automatic insertion of control and/or safety rods):

- Manual Trip--Operator activation of any of the three safety circuit pushbuttons. No. 1 would insert both VSRs and HCRs, No. 2 would insert HCRs, and No. 3 would trip the $3 X$ safety device.

- Power Failure--Loss of normal supply of electrical power would automatically insert the HCRs and VSRs by activating a low-voltage relay.

- Beckman-Neutron Flux Monitor--Four ion chambers in the reactor measured the neutron density in four regions of the reactor. These were signalled to four picoammeters in the control room which held adjustable trip points. The value at which the trips were set was specified in the Process Standard. The HCRs and VSRs were automatically inserted if the trip point on picoammeter was reached.

As time went on and there were requests for higher production, it was necessary to operate closer to the safety limits. This was made possible by adding more monitoring devices that would shut the reactor down automatically when the safety limit was approached. The following trip requirements were added to those above.

- Pressure Monitor--The pressure monitor system, sometimes referred to by the gauge manufacturer's name, "Panellit," measured coolant 
flow continuity in each of the 2,004 process tubes. A venturi or orifice was located at the inlet of each tube and, from it, a single hydraulic sensing line extended to the reactor control room and the pressure monitoring gauge. Each gauge consisted of a coiled Bordon tube which rotated a dial through mechanical linkages. The pressure trip points, high and low, were set by positioning two magnets mounted on the dial which operated a mercury switch. When the trip point was reached, the switch opened, causing the HCRs and VSRs to scram.

Installation of this trip requirement essentially added 4,008 trip possibilities to the safety circuit and required considerable finesse in startup of the reactor. The Panellit gauges measured pressure changes within a range of $50 \pm 1 \mathrm{~b} / \mathrm{in}^{2}$ (gage) and did not show absolute pressure. During startup of the reactor, the change in viscosity of the coolant flow would change with the increase in temperature. This change was reflected in the pressure and, since each process tube operated at a slightly different level, it was necessary to have at least 3 operators scanning the 2,004 gauges to alert the control room supervisor to a near-trip condition so that the bulk inlet pressure could be adjusted accordingly as power levels were increased. The first startup with the tube pressure gauges in the circuit occurred at B Reactor and, in the period of one shift, the Panellit tripped the scram circuit eight times. As experience was gained, the Panellit trips on startup were essentially eliminated.

- Seismoscope--Three seismoscopes were installed. Two were connected to the trip circuit and both had to trip to cause the HCRs and VSRs to scram. The third seismoscope was set to annunciate at an earthquake of low magnitude, but not serious enough to require a shutdown.

- VCR/HCR Interlock--This interlock prevented removing HCRs from in-core position before the VSRs were withdrawn.

- Zone Temperature Monitor--A special monitoring system was installed to measure the outlet temperature of the coolant from 211 different process tubes. The 211 tubes were in a configuration so that one tube was considered to represent an area encompassing 9 process tubes. The system was set to insert the HCRs and VSRs when two adjacent sensors exceeded a preset limit. The sensors were resistance temperature detectors (RTD) installed in the rear outlet assembly of the respective tubes.

- Bypass Switches--Bypass switches were installed on each system to facilitate maintenance on the respective system. The bypass switches were wired so that bypassing more than one switch at a time would cause a scram.

- Process Water Pressure--The pressure in each of the coolant supply risers was monitored by a set of Mercoid switches. Three settings 
WHC - EP- 0273

were used: low pressure (LP), very low pressure (VLP), and extra low pressure (ELP). The LP and VLP trips were set to trip the Ba11 $3 X$ System if the pressure decay were faster than a fixed rate. Activation of the ELP would automatically trip the Ba11 3X System.

3.3.3.2 Reactor Process Control Instrumentation. Instrumentation, other than that used for safety circuit action, was necessary if the reactor were to be controlled efficiently. In some situations, manual scramming of the reactor was required when indicated readings reached predetermined values.

The nuclear instrumentation range requirement was from normal background or shutdown flux levels to approximately one hundred billion times normal background. A single instrument was not available with a range this large. This required that instrumentation be divided into different systems that monitored reactor operation at various flux levels.

- Low-Level Neutron Flux Monitor--At background or shutdown levels, the Low-Level Neutron Flux Monitor System (Subcritical Monitor) was used. This system comprised two separate and identical channels, each composed of a fission chamber mounted on a screwdriven mechanism and an amplifier-counting circuit, indicating period and audible alarms when a 15-s rising period was reached. The primary use of this system was to determine when the reactor achieved criticality and to indicate the magnitude of the rising period during low power level operation at startup.

- Galvanometer System--The galvanometer system operated from a current source of one ion chamber. Two galvanometers were connected in series, one providing a signal (deflection) proportional to neutron flux power level and the other showing deviation from a preset level. The readout equipment, including shunts and potentiometers, was located at the reactor control console.

- High-Level Neutron Flux Monitor--The safety system nuclear monitoring system (the Beckmans) was discussed previously in the section on safety circuits.

3.3.3.3 Temperature Monitoring. Temperature monitoring was divided into three categories of instrument systems: effluent water temperature monitoring, moderator (graphite) temperature monitoring, and thermal shield temperature monitoring.

- Effluent Water Monitoring--A thermocouple was installed at the outlet end of each process tube to measure the temperature of the cooling water leaving that tube. Each thermocouple was connected to a plug board in the control room. A series of stepping relays was used to scan the thermocouples by rows, in numerical order. The plug board was used to select individual tube temperatures manually for recording data in various forms. Two recorders were provided for individual trend-recording of temperatures: one for 
traversing selected tube temperatures in process tube order and one for recording the temperatures from a preselected number of tubes representative of different zones in the reactor, and signaling any in excess of a variable set point.

The outlet temperature of each process tube was used to compute the production in the respective tubes. It was necessary to provide a hard copy of the temperature of each tube each operating day. In the early stages of operation, this data was typed manualiy on a temperature map. It usually took two men about 2 to $3 \mathrm{~h}$ to prepare this data. In 1952, a flexowriter was developed to automatically read and type the data in about $10 \mathrm{~min}$.

Reactor bulk outlet water temperature was measured by means of an RTD located in the reactor downcomer. This temperature was recorded in the control room and was also used in a power calculator.

A linear power rate-of-rise system was developed and placed in service in the mid-1950s. The system operated from RTDs located at the outlet of ten process tubes uniformly distributed over the rear face of the reactor. The circuit averaged and then differentiated the signals of the RTDs to show the linear increase or decrease in average power level in megawatts.

- Moderator Temperature Monitor--Thermocouples were originally embedded in the moderator to measure the distributed temperature of the graphite. A large percentage of the original thermocouples failed, so it became necessary to provide another means for obtaining this temperature information. Eleven thermocouples were placed in stringers of graphite beads and inserted in a process tube channel. Seven process tube channels were dedicated to this temperature monitoring service.

- Thermal Shield Temperature Monitor--Thermocouples were distributed in the thermal shield to maintain temperature control. Shield temperatures were limited to minimize thermal deterioration of the biological shield masonite and to prevent melting of the lead wool packing around the outside of the shield cooling tubes.

3.3.3.4 Miscellaneous Coolant Water Instrumentation. Many miscellaneous pressure gauges in the control room indicated the pressures at various points in the primary and secondary coolant systems. Included in these measurements were top of inlet riser pressure, crossheader pressures, top of downcomer pressure, control rod coolant pressures, and high tank level and pressure, and export system pressure.

3.3.3.5 Rupture Monitor. The rupture monitor system detected fuel element failures in the reactor. It continually sampled effluent water from both ends of the rear crossheader before the effluent entered the rear riser. Originally the effluent sample passed by a radiation detecting chamber which measured the beta radiation level. Because the radiation level in the sample would vary with power level changes and shifts in the flux distribution, 
there were many false indications of a fuel failure inhibiting early detection of a fuel failure. In the mid-1950s, a gamma monitoring system was developed and installed. A scintillation counter scanned the effluent sample and measured the rate of gamma emission in the energy band of 2.1 to $3.2 \mathrm{meV}$ emanating from the sample. The measuring system compensated for power level by using $\mathrm{N}^{16}$ activity as a reference. Visual and audible alarms annunciated when trip points were exceeded.

3.3.3.6 Reactor Power Level Calculator. The total power level of the reactor was computed by a calculator using total flow to the reactor and the bulk coolant temperature increase across the reactor. The total power level was recorded on a circular chart. The power deviation from a preset power level value was also recorded on a strip chart located at the operator console.

\subsection{FUEL}

Fuel elements were normally shipped by truck from the fuel manufacturing plant in the 300 Area to the reactor. The fuel elements were stored in their shipping pallets in the 103 Building adjacent to the 105 Reactor Building until a few days before a charge/discharge outage, when the pallets would be moved to the work area in the 105 Building to be made up in charge boxes.

The initial charge was autoclaved and given a second detailed inspection in the 111 Building, which was located at the west end of the 115 Building, before being placed in charge boxes. Also, initially the fuel elements were shipped in boxes that would hold six fuel elements standing on end with a cover on the box.

The original fuel elements were about 8 -in. long and 1.5-in. in diameter. The solid cylinder of uranium was clad in an aluminum alloy bonded to the uranium by a layer of eutectic aluminum-silicon alloy. The fuel was predominantly natural uranium. To provide excess reactivity and power flattening, enriched uranium fuel $(0.947 \mathrm{wt} \% 235 \mathrm{U})$ was also used. The enriched fuel was 6 in. long to allow differentiation between it and the regular fuel for irradiated fuel storage control.

In the planning stages of the project, the fuels manufacturing process was considered to be a simple application of state-of-the-art metalizing and bonding of the two materials. However, because of the oxidizing characteristics of the metallic uranium, a crash program had to be implemented to produce enough acceptable bonded fuel to meet the B Reactor startup date. As a contingency measure, a complete reactor load of unbonded fuel was produced to meet the startup schedule, if necessary. The use of unbonded fuel would have significantly limited the plutonium production rate.

As power levels were increased to increase production rates, the fuel element temperatures became a controlling factor. As a result, there were continual fuel technology developments that ultimately changed the fuel geometry from a solid to a tubular cylinder, enabling coolant to flow through the center of the fuel element, as well as outside. 
The graphite distortion problem required that shorter fuel elements be used in the extreme fringe of the reactor to pass through the distorted portion of the process tube. Distortion in the fringe was more pronounced, because the graphite temperatures in the outer regions of the reactor were lower. The length of the shorter fuel was about 4 in.

\subsection{REACTOR REFUELING}

The normal method of refueling was displacement charge/discharge during a reactor shutdown. Refueling would occur about once a month and would involve about $10 \%$ of the process tubes. The procedure used is illustrated in Figure 8.

During a charge/discharge operation, the tubes to be discharged had the rear nozzle caps removed. All personnel were then evacuated from the rear work platform, and the platform raised to the top of the unit.

Electrical interlocks prevented operation of the charging equipment on the front work platform until the rear work platform was raised to the top limit of travel and all rear entryways were closed.

The front-face charging activities consisted of transferring the loaded charge boxes from the work area floor to the charge work platform. The inlet nozzle cap of the process tube was removed and the desired number of aluminum spacers were inserted into the tube by hand. The charging machine was then connected to the process tube nozzle. The fuel elements were removed manually from the charge box and placed on a gravity feed tray on the charging machine. The fuel elements were pushed into the process tube by a reciprocating ram, causing the displacement of the irradiated fuel elements in the tube and discharging into the discharge basin.

Initially, tip-offs were placed on the rear of the tube being discharged to project the fuel elements away from the capped tubes below. Through experience, the tip-offs were found to be an unnecessary step in the procedure and were eliminated.

Also, during the first several years of operation the fuel was manually charged/discharged. This was done by adapting a wooden $6-\mathrm{ft}-1$ ong 4 by 4 to the front nozzle. A "V" slot was cut in one side of the 4 by 4 . The fuel elements were placed in the "V" slot and, with a long push pole, the operators pushed the new fuel into the process tube, displacing the irradiated fuel. 


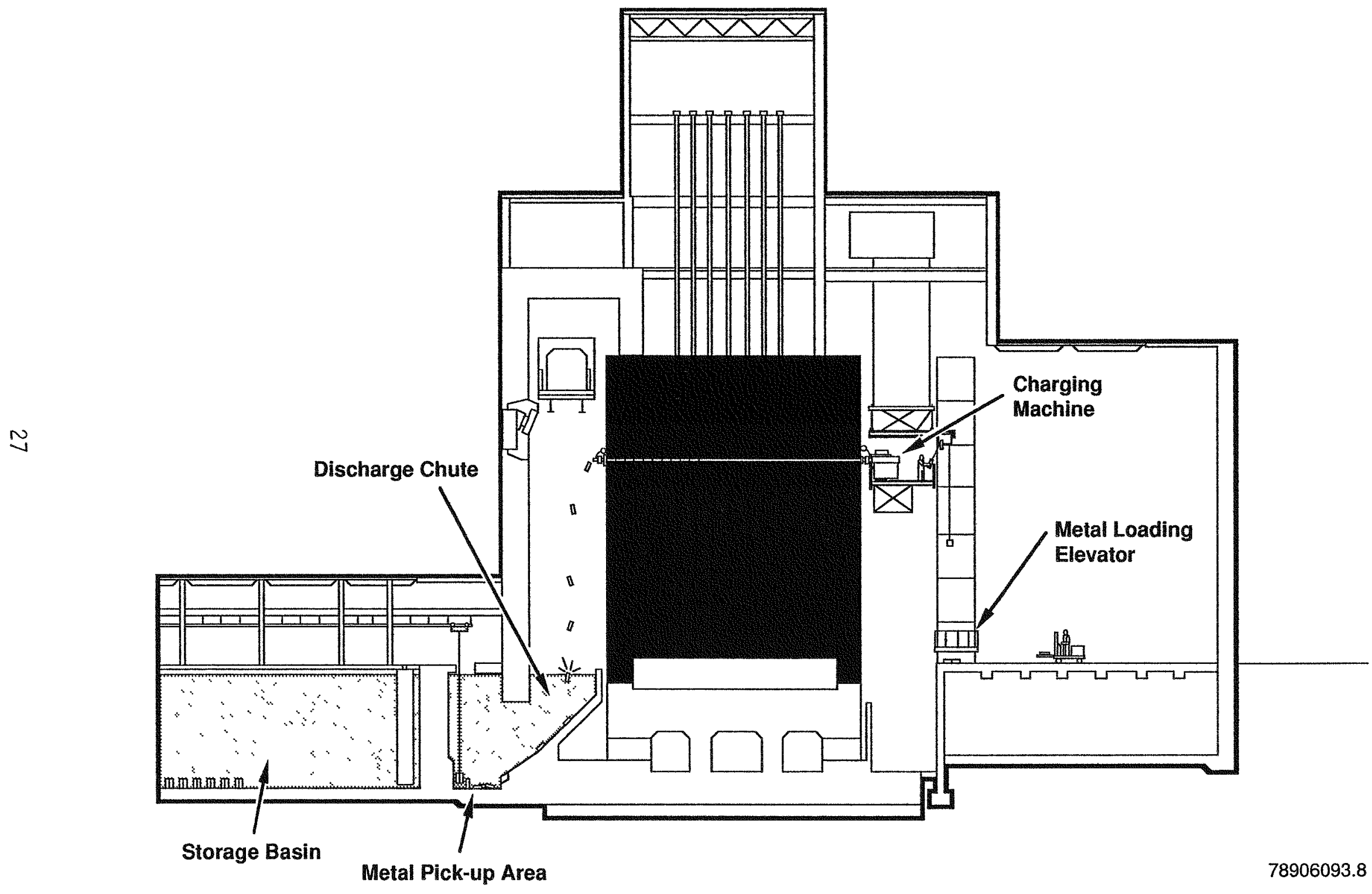

Figure 8. Refueling 0peration. 
WHC-EP-0273

\subsection{POST-IRRADIATED FUEL HANDLING}

Post-irradiation handling of the natural uranium fuel elements presented no criticality problems. The discharged irradiated elements dropped into a water-filled discharge chute and slid down into the metal pickup area at the reactor end of the storage basin. The water in the storage bas in was about $20-\mathrm{ft}$ deep and provided ample radiation shielding for personnel. The natural uranium elements were generally allowed to accumulate in the discharge chutes until the end of the refueling procedure, at which time they were transferred to storage buckets by means of long pickup tongs. The loaded buckets, each of which held about 250 fuel elements, were moved to storage by electric hoists and a monorail system. There were no restrictions in the storage of irradiated natural uranium. Shipment of the irradiated elements from the reactors to the separations plants was by rail in a cask car with no restrictions, other than those imposed by physical limitations, on the number of natural elements to be loaded or shipped in a cask.

Restrictions were imposed on handling, storing, and shipping of irradiated, enriched uranium fuel elements depending on percent of enrichment.

Initially, the Manhattan Project plan called for shipping irradiated fuel to an interim storage for fission product decay. To this end, three small storage basin facilities were built between the 100 and 200 Areas. The site is identified as the 200-N Area with the building identity of $212-\mathrm{N}, P$, and $R$. To the knowledge of the writer, on one occasion there were only a few buckets of irradiated fuel stored in the 212-R Building. The facilities were found to be unnecessary. Adequate storage space in the 105 storage basin was developed by "cording" fuel in buckets, rather than "jackstrawing" the fuel.

\subsection{BUILDING VENTILATION}

Approximately $100,000 \mathrm{ft}^{3} / \mathrm{min}$ of outside air was circulated through the 105 Reactor Building. Two supply fans were coupled to electric and steam motors. The normal drive was an electric motor with the steam turbine backup. The outside air was washed, filtered, and tempered in passing through the supply fans. The balance of air in the building was controlled so that a11 air exhausted from the shops, offices, and work stations to the radiation zones and out through the exhaust system.

The exhaust system originally consisted of four exhaust fans: two electric-driven and two steam-driven. The two electric-driven fans were the normal operating fans with the steam turbine-driven fans used as backup. A slight negative pressure was maintained in the building at all times. The exhaust fans discharged into an underground ventilation tunnel connecting the fan discharge plenum to a $200-f t$-high reinforced concrete stack.

In 1960 , confinement facilities were installed in the reactor building to control the release of radioactive matter from the reactor building in the event of a nuclear incident. The method of control was to confine the flow 
of ventilation air in the building to a definite path, and to exhaust it through absolute and charcoal filters before release to the stack. The confinement zone in the 105 Building was defined as the rear face, the work area, the top of the reactor, the $X$ levels, the inner rod room, and the exhaust tunnel. The ventilation stack was identified as $116-B$, the underground confinement filter facility as 117-B, and the instrument sampling building for the confinement system as 119-B. The ventilation stack, filter building, and instrument building were all located in a cluster on the northwest end of the 105-B Building.

A fog spray system was installed as part of the confinement project. The fog spray system was located in the rear face enclosure and produced a finely divided spray of water for absorbing a portion of the halogen vapors released during a uranium fire, settling out a portion of the airborne particulate matter released during fuel element fires. The event for which the fog spray was designed never occurred at B Reactor.

\subsection{OFFICE AND SERVICE BUILDINGS}

A number of office and service buildings were located in the 100-B Area. These are listed in the following paragraphs with a brief explanation of their use.

\subsubsection{Building}

This was a concrete block, four-story building which was to serve as a water quality laboratory. The 108 Building was used for its designed use for a short period of time; it was converted to a mechanical development laboratory and then used in 1948 to 1952 as a pilot line for tritium separations. The feed material for the tritium separation was irradiated in the 105-B Reactor. A 200-ft ventilation stack and 104-B1 and B2 Buildings were added to the 108-B complex for the tritium program. Building 104-B1 was an interim storage facility and Building 104-B2 was the product storage building. Both buildings were relatively small structures.

\subsubsection{8-B Contaminated Drain Transfer Station}

This facility served as a collection station for all the contaminated drains in the 105 Building and for the cooling flow from the fuel storage basin. Water was transferred from this station to the reactor effluent lines using deep well pumps.

\subsubsection{1-B Emergency Alternator}

The 1621-B Building was a portable, wooden-frame building that housed an alternator and battery for emergency lighting and instrument power to the 105 Building. 
WHC-EP-0273

\subsubsection{1-B Electrical Equipment Storage}

This was an old, wooden building left by construction forces and used temporarily for electrical equipment storage.

\subsubsection{1-B Main Gate House}

Originally the perimeter fence enclosed an area almost twice as large as the area enclosed at the time of deactivation. The main gate house was located about one-half mile directly east of the 108 Building. When the enclosure was reduced, the main gate was located adjacent to the 108 Building. The 1701 Building was a two-story, wooden structure with about $943 \mathrm{ft}^{2}$. The lower floor was used by Patrol to issue and check badges of people entering the area. Two badges were required to enter the area. Each employee cleared for entry to $100-B$ had an identity pass with his/her picture, similar to a drivers license, with clearance classification. A second picture badge with a photo film pack was issued at the badge house. The two pieces of identification were required to work inside the area. Ionization "pencils" were also issued to employees expected to work in a radiation zone. The second floor of the 1701 Building was used by what was known as the Badge Processing workers. They replaced the film packs in the badges and measured the discharge in the ionization pencils. The building was sold to a salvage contractor and dismantled.

\subsubsection{2-B/105-B Exclusion Area Badge House}

This was a wooden-frame building with $400 \mathrm{ft}^{2}$ of floor space. It was used by Security Patrol to make a security check of all employees entering the 105 Exclusion Area. The original building was replaced with a larger, concrete-block building containing a lunch room, locker room, and restroom for Patrol personnel. The new facility was built when the main gate, 1701-B, was abandoned.

\subsubsection{4-B Office Building}

The office building provided offices for area administrative and technical personnel. It was a " $T$ "-shaped building with approximately $8,000 \mathrm{ft}^{2}$. The building was a wood frame on a cement block foundation. A $12-\mathrm{ft}$ by $12-\mathrm{ft}$ poured reinforced concrete room with $3-\mathrm{ft}$ thick walls was located in the northeast corner of the building. The room was used as a vault to store classified materials. The building was moved to the 200 Area and set up as an office building.

\subsubsection{7-B Change House}

During the first few years of operation, smoking and eating were not permitted in the 105 Building. The 1707-B Change House served as a lunch room and change room for the employees with regular assignments in the 
105 Building. In the late 1940s, when smoking and eating were permitted in the 105 Building, the change and lunch facilities were moved to 105; and 1707-B was converted to an office building. The building was wood-frame construction and had a floor space area of about 2,000 $\mathrm{ft}^{2}$. Following deactivation, the building was sold to a salvage operator, dismantled, and removed.

\subsubsection{7-AB Maintenance Change House}

This building served the same purpose as the 1707-B Change House, except that it was used by Maintenance personnel; it remained a change house until after deactivation when it was sold to a salvage operator.

\subsubsection{9-B Fire Headquarters}

This facility served as a fire station until the mid-1960s, when the fire headquarters for the 100 Areas were centralized and located at the crossroads to 100-B and 100-D Areas. The building was constructed of wood and covered an area of about $2,000 \mathrm{ft}^{2}$. The building was sold to a salvage operator in the early 1970s, dismantled, and removed.

\subsubsection{3-B Store Room and Warehouse}

A11 supplies used in 100-B Area were received and dispersed from Building 1713-B. Until about 1949 there was no Central Stores. The building was wood-frame construction and had about 4,100 ft $\mathrm{ft}^{2}$ floor space. The building was converted to an instrument development and testing shop following the centralization of stores. The building was sold to a salvage operator, dismantled, and removed.

\subsubsection{5-B $0 \mathrm{il}$ and Paint Storage}

This was a smal1, $600 \mathrm{ft}^{2}$ building used for storing lubricating oil and paint. It was a single-story, frame building. Following the deactivation of $B$ Reactor, the building was demolished and buried in the 184 coal pit.

\subsubsection{6-B Automotive Repair}

A11 automotive vehicles assigned to 100-B Area were lubed and serviced in this facility. It was a single-story, frame building equipped for a service station function. The building covered an area of about $1,800 \mathrm{ft}^{2}$. Lubrication of vehicles was accomplished from a grease pit dug in a high-bay area of the garage. 
WHC-EP-0273

\subsubsection{7-B Area Maintenance Shops}

The 1717-B Building housed carpenter, millwright, welding, pipefitter, and painting crafts. Limited facilities were available for machine and fabrication work. The structure was wood frame, and had a total area of $12,500 \mathrm{ft}^{2}$. Following deactivation the building was sold to a salvage operator, dismantled, and removed.

\subsubsection{9-B First Aid Station}

This facility contained a first-aid room, examination room, laboratory, ward, office, and sanitary facilities. It was a single-story, frame structure with $930 \mathrm{ft}^{2}$ of floor space. Following deactivation, the building was sold to a salvage operator, dismantled, and removed.

\subsubsection{0-B Patrol Headquarters}

This building served as headquarters for the Hanford Security Patrol personnel assigned to 100-B Area. It included offices, a change room, a lunch room, and clothing and equipment storage rooms. The building was a frame structure with 2,500 $\mathrm{ft}^{2}$ of floor space. This facility was vacated in about 1965 when Patrol Headquarters was centralized and moved to a new location. The building was modified to provide several offices for administrative personnel. Following deactivation of $105-\mathrm{B}$, the building was sold to a salvage operator, dismantled, and removed from the project.

\subsubsection{2-B Paint Shop and Riggers Loft}

This was a single-story, frame structure used by the painter and rigger crafts as a central station for their assigned work. The building contained painting and rigging supplies. There was a total of $1,200 \mathrm{ft}^{2}$, shared equally by the two crafts. Following deactivation, the building was sold to a salvage operator, dismantled, and moved.

\subsubsection{6-B Storage Building}

This was a sheet-metal Butler building with a wood floor used by Maintenance personnel for storage of seldom-used tools and equipment. This building was a portable work station used by construction forces during one of the project activities. When the project was complete, B Maintenance requisitioned the building for its use. Following deactivation, the facility was demolished and disposed of in the 184 coal pit. 


\subsection{STARTUP}

A11 operating procedures had been completed and the startup crews were being assigned to 100-B Area by June 1944. Top physicists and scientists started arriving on plant during the same time period. A number of personnel who were to be assigned supervisor and technical responsibility were trained off-plant and started arriving on-plant in June. The operation crews were busy making equipment break-in runs, performing acceptance tests, and receiving on-the-job training.

On September 13, 1944, Operations assumed responsibility for 100-B Area. Charging fuel in the reactor started immediately. The initial charging of fuel was a lengthy procedure, with many delays for various physics and calibration checks. Because the start up at 100-B was the first of its kind with every step proving another unknown and recognizing the potential hazards, each step was taken with the utmost care and caution.

Production operation was achieved at 10:48 p.m. on September 26, 1944. Shortly following startup, the reactor showed an unexplained gradual loss of reactivity and reached zero power with all rods out. In the following few days, a number of possible causes for the loss of reactivity were eliminated. In the process of several startups and shutdowns to explore the possible cause of the problem, it was determined that the nuclear reaction was producing an element that was causing the loss of reactivity. With the information gained from the above, the scientists headed by Enrico Fermi determined the element to be xenon $(135 \mathrm{xe})$, an isotope formed in the fission process. Power level ascension continued in steps for the next 4 mo, until the design level was attained on February 4, 1945. Even though the xenon problem slowed the startup and ascension period, sufficient plutonium was produced to meet the needs of schedule.

The construction and startup experience at 100-B Area saved considerable time and money in construction and startup of 100-D and 100-F. A quote from a logbook recorded by the Corp. of Engineers states, "The experience gained in 100-B has been extremely valuable in reducing the time of construction on the 100-D and 100-F areas." 
WHC-EP-0273

This page intentionally left blank.

\section{DO NOT MICROFILM THIS PAGE}




\subsection{OPERATION}

The production operation at 100-B Area started on September 26, 1944. The first fuel elements enriched with plutonium were discharged on November 28, 1944, to provide material to test the separations process. The first routine production discharge occurred on Christmas Day, 1945. The 100-B production facility continued operation until April 3, 1946, when the facility was placed on wet standby pending an evaluation of the nation's plutonium needs. A restart was made in July 1948, and operations continued until the facility was shut down and deactivation started on February 12 , 1968. Highlights of operations at 100-B Area are as follows.

- Design power operation was achieved on February 4, 1945.

- A pilot program for tritium extraction was started in the 108-B Building in February 1949 and continued until March 1952. The program included exposure of the feed material in the reactor, packaging the material in the 105-B storage basin for transfer to 108-B, and separation of the tritium from the feed material. The tritium from this process was used in the first hydrogen bomb tested.

- The first fuel element failure occurred in the 105-B Reactor in 1948 , shortly after startup from the extended standby outage. A period of 2 yr passed before the second fuel failure occurred. The fuel failure rate was a function of fuel temperature and, as power levels increased, the frequency of failures increased. However, improvements in fuel technology, operating techniques, and restrictive process limits permitted significant increases in production rates without increasing the fuel failure rates.

- Power level started increasing above design level in the early part of 1949. Power level increases continued in increments during the next several years as operating improvements were made.

- Plutonium produced in the 100-B Area was used in the test bomb that exploded in New Mexico in the summer of 1945 and in the atomic bomb that was exploded over Nagasaki, Japan, in August 1945.

- In December 1956, 100-B was shut down for about 6 wk for a major project (CG-558) which doubled the coolant flow capabilities to the 105-B Reactor and resulted in a corresponding increase in production rates. The project included installing new primary coolant pumps, upgrading all the support facilities, replacing the inlet hardware on the process tubes, and upgrading the effluent piping from the reactor to the effluent lines and the 107 retention basin.

- The chemicals used in treating the reactor coolant played an important role in corrosion rates in piping, fuel elements, and reactor components, and had a significant effect on production and 
operating efficiencies. There was a continuing effort throughout the operating history of the plant to maintain the optimum water quality. These efforts contributed significantly to the production achievements made at 100-B and should be recognized for this contribution.

- A method for measuring the residual wall thickness of the process tubes was developed in the early 1950s. A routine monitoring program for measuring the wall thickness was implemented, and, by 1956 , corrosion of the process tubes had progressed to a point where replacement of the process tubes became a routine preventive maintenance program. The predicted life of a process tube in the high power regions of the reactor was about 5 to $7 \mathrm{yr}$. During the history of operation at 100-B, approximately 3,500 process tubes were replaced.

- When the reactor was shut down from an equilibrium operating level, the inherent characteristic of the process was such that a restart had to take place within approximately one-half hour. Otherwise, about 24 to $36 \mathrm{~h}$ had to lapse before a startup could be initiated. This resulted in a need for precise planning and innovative procedures to minimize nonproductive outage time. One such procedure was a "quickie" discharge of a fuel failure. In this procedure special equipment was developed to remotely remove a rear process tube cap with full shutdown cooling flow on the tube. The tube of fuel containing the failed fuel element was discharged, the rear cap replaced, and the reactor restarted within the 30-min restart time, thus eliminating up to $30 \mathrm{~h}$ of outage time.

- Each new event was a first, requiring ingenuity, imagination, and a good understanding of the systems and controls to ensure a safe and expeditious resolve.

- A number of different contractors managed the operation of the plant. E. I. du Pont de Nemours \& Company constructed and operated the plant for $2 \mathrm{yr}$. They were followed by General Electric, who operated the plant from September 1946 until 1964, when the Hanford Site Operations was decentralized and Douglas United Corporation became the prime contractor for operation of facilities in 100-B Area. Douglas United was reorganized and became United Nuclear Corporation in 1970, and, later, UNC Nuclear Industries. Consolidation of many of the operations at the Hanford Site, including 100-B, was implemented in June 1987 by the U.S. Department of Energy-Richland Operations Office and contracted to Westinghouse Hanford Company. 


\subsection{DEACTIVATION}

The 105-B Reactor and support facilities were shut down for the final time on February 12, 1968, ending $23 \mathrm{yr}$ and 5 mo of active service. The reactor was defueled and all related systems were deactivated during the following 6-wk period. The 100-B was maintained for the next $12 \mathrm{yr}$ in standby status with a restart capability of 18 to $24 \mathrm{mo}$. The 100-B Reactor was the fifth in a series of eight production reactors at the Hanford Site to be deactivated, so the procedures were routine and performed without incident. A part of the 100-B water plant has remained active to supply raw river water to the 200 Areas. A11 other structures and facilities were declared excess in the early 1980s.

The 105-B Reactor is included in the draft Environmental Impact Statement for decommissioning the eight surplus reactors, with an option to establish it as a historical site and, possibly, open it for public tours. In the interim, the facilities at $100-B$ are being maintained in a protective storage mode.

In 1976, B Reactor was designated a National Historic Engineering Site by the American Society of Mechanical Engineers (ASME). 
WHC-EP-0273

This page intentionally left blank.

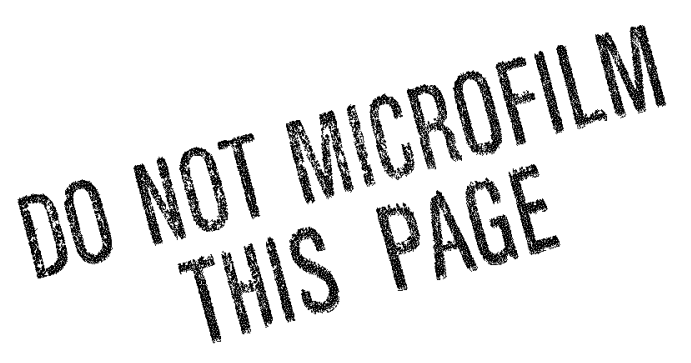




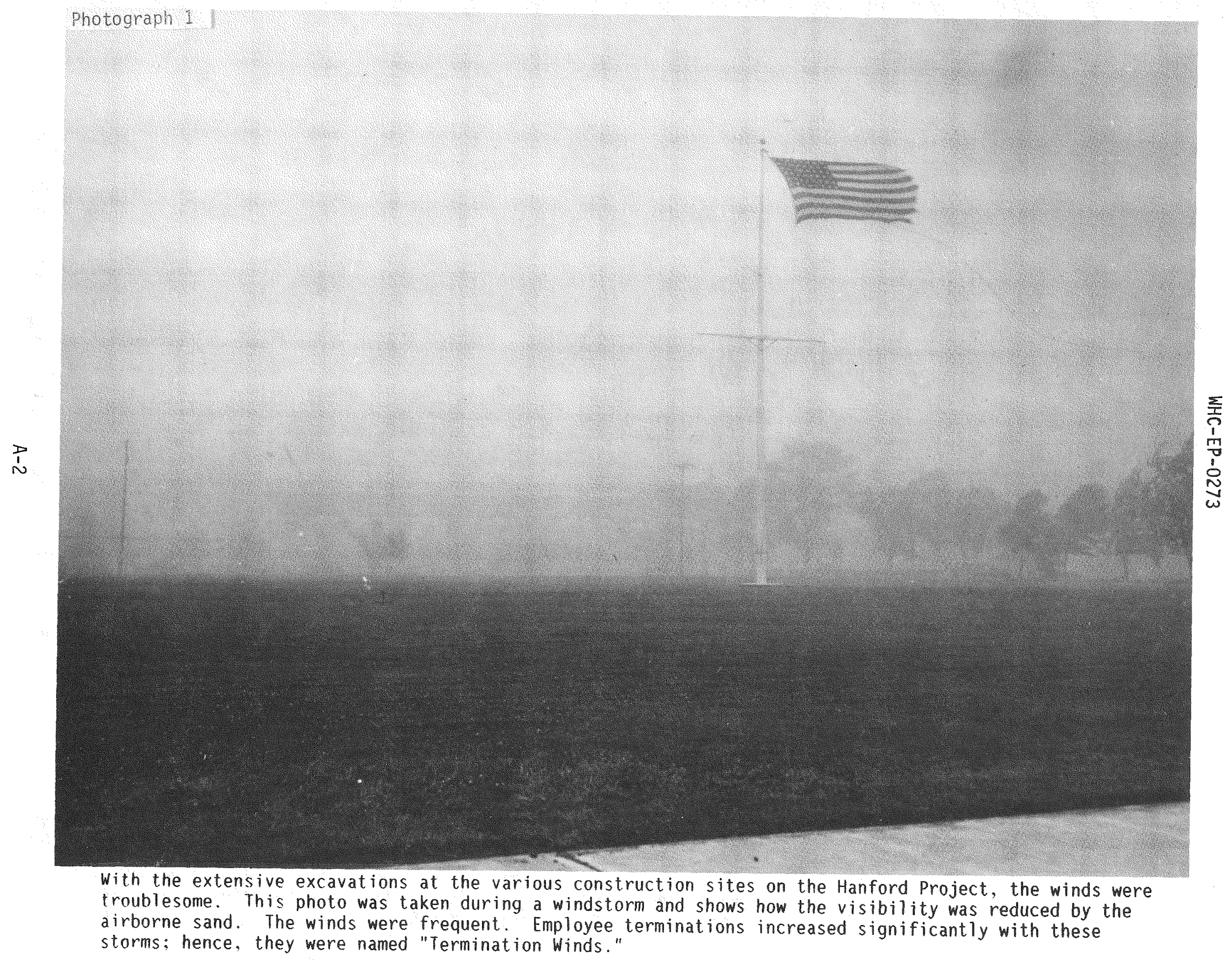




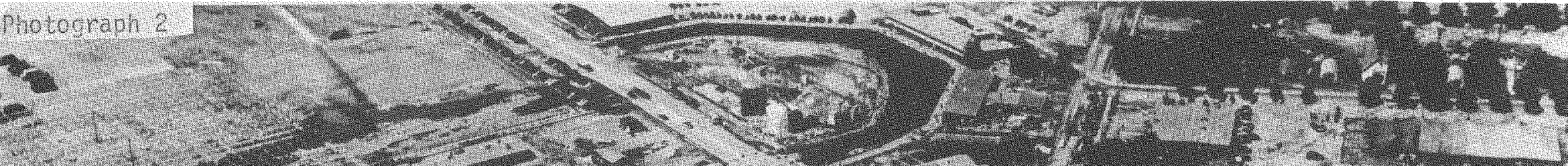

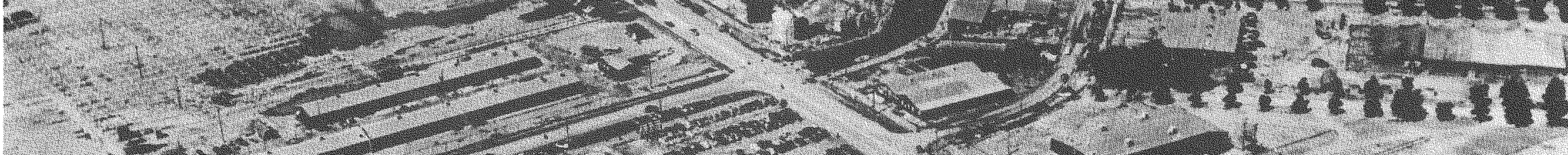
-

(t)

$\stackrel{P}{i}$
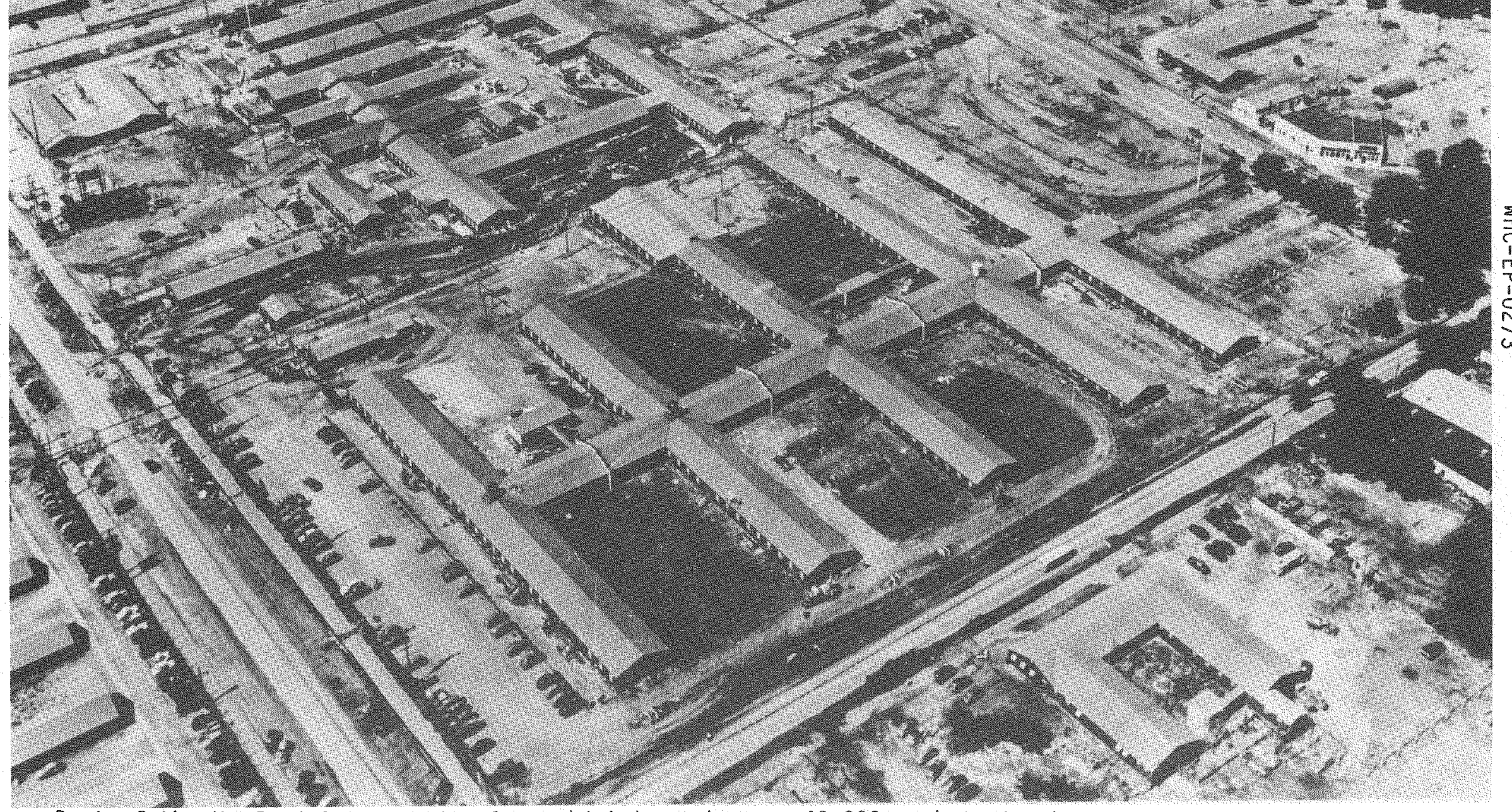

Part of the Hanford Construction Camp which housed up to 40,000 workers is shows in this photo. The view centers on the Administration Area of the Construction iamp. 
hotograph 3

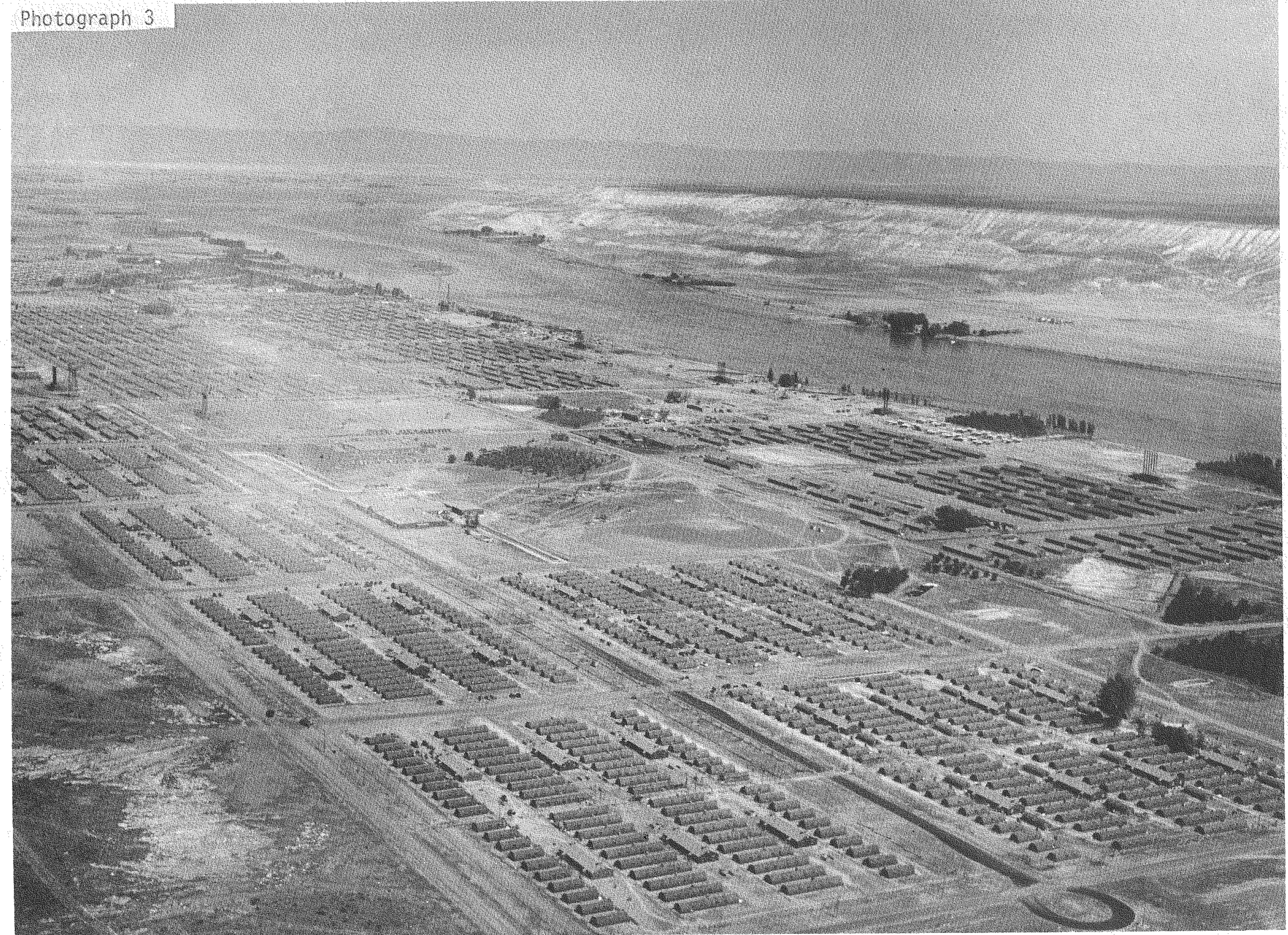

This photo shows the living quarters at the Construction Camp. 


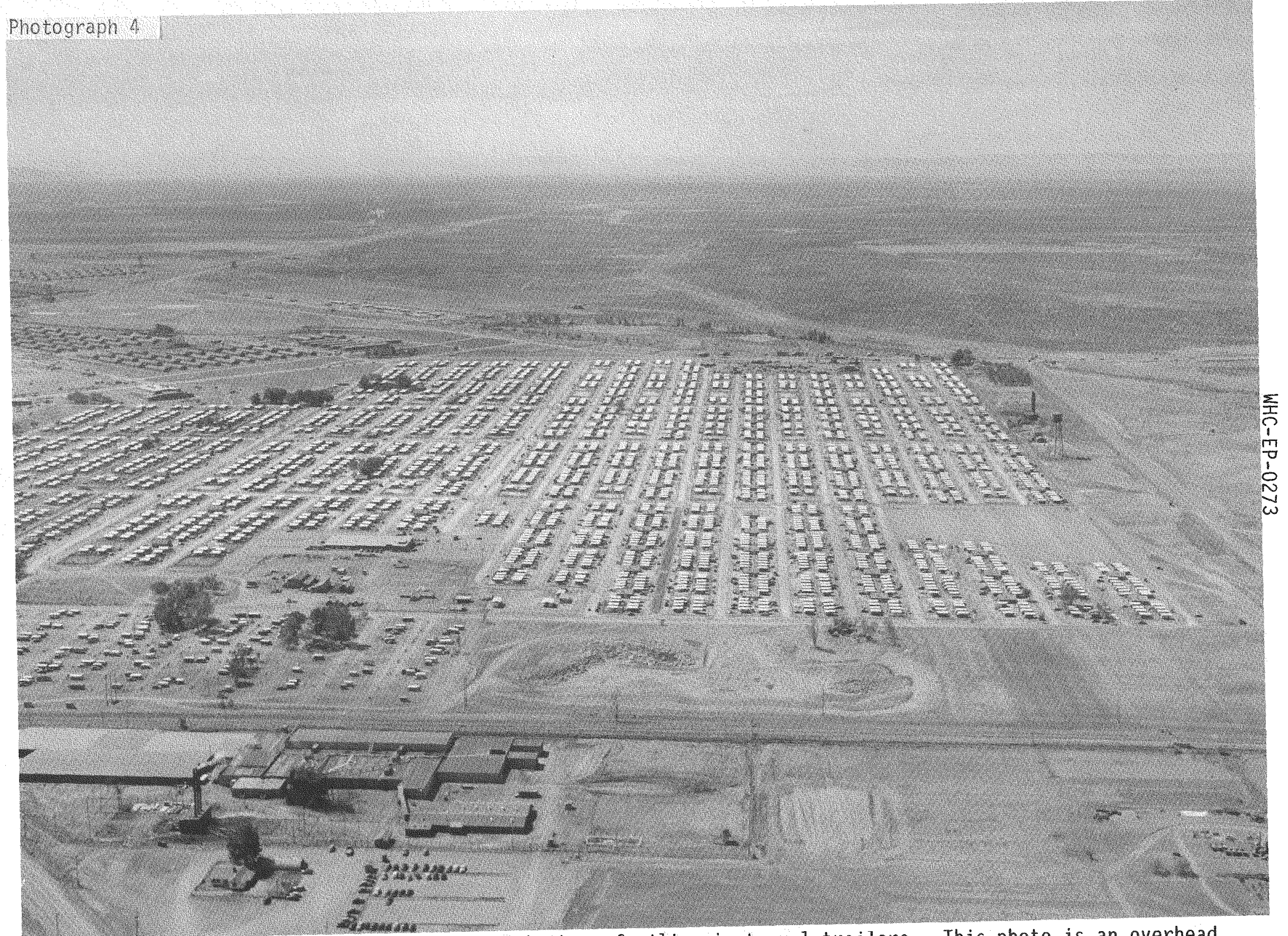

Some of the construction workers lived with their families in travel trailers. This photo is an overhead view of the trailer park at the Hanford townsite. The structures that are shown are wood canopies built over the trailers to shield them from the weather. 


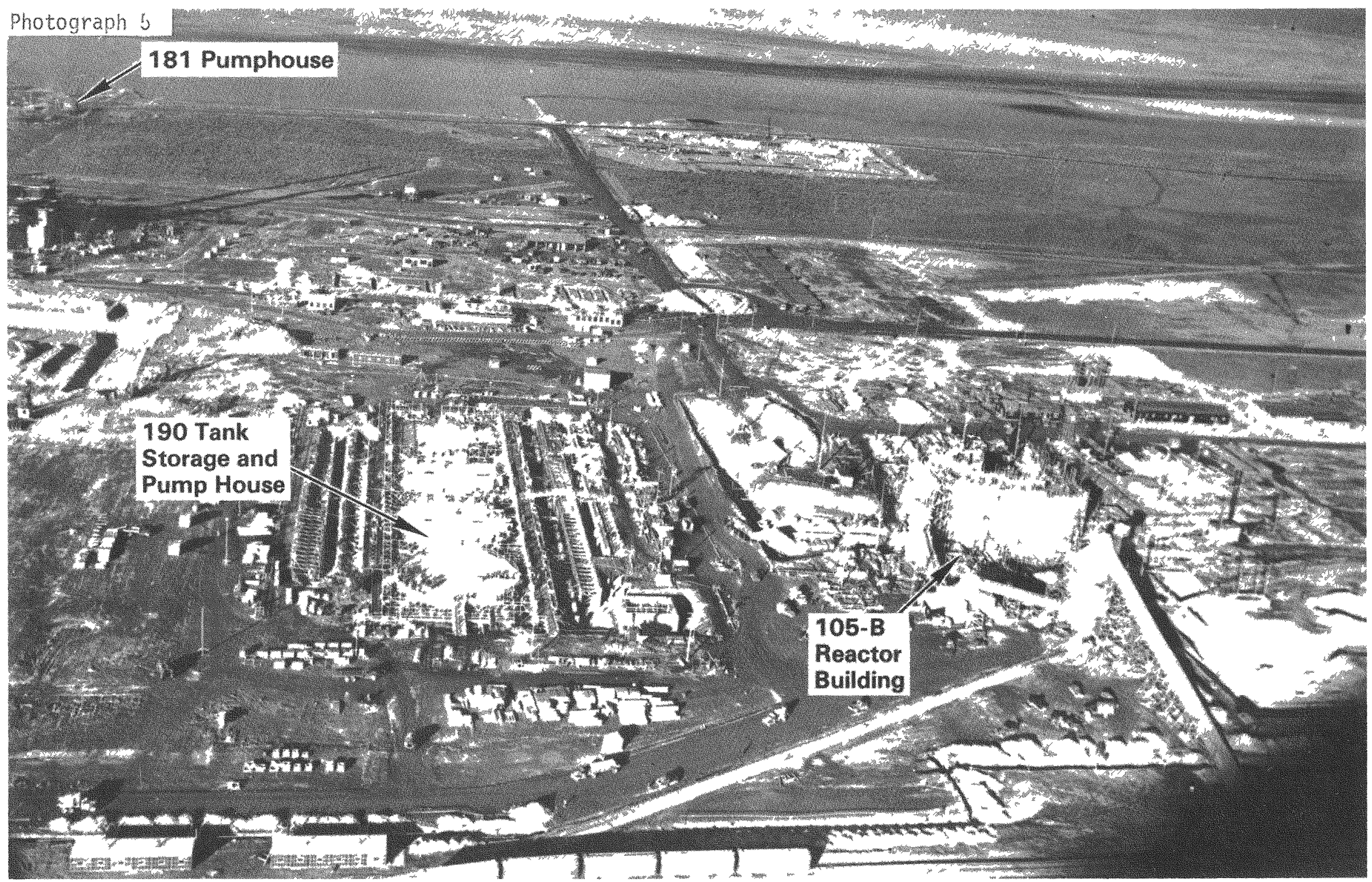

This photo and the next two show the progress of construction at the 100-B Area. The primary buildings are identified in the photos by their respective numbers. 


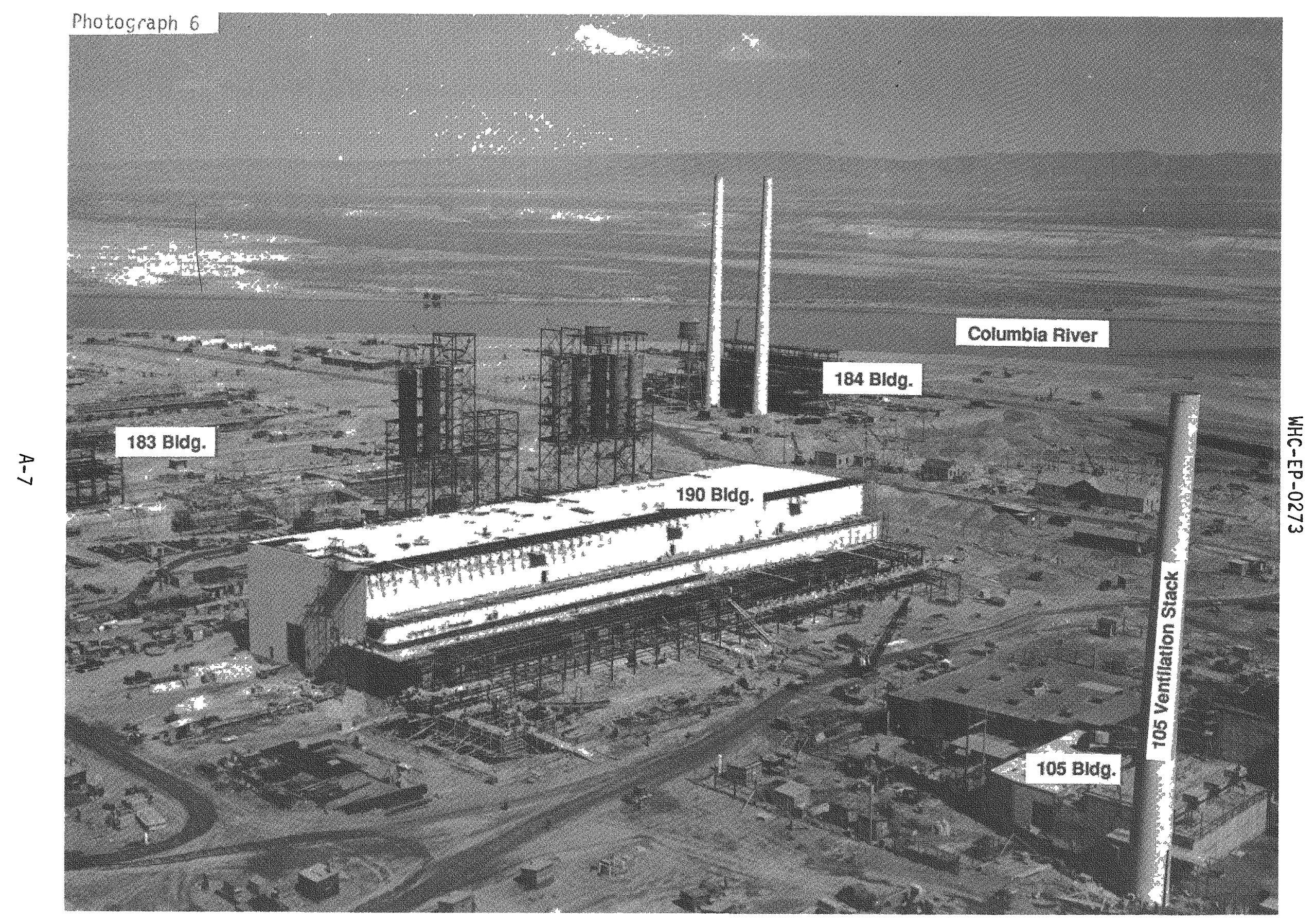


Photograph 7

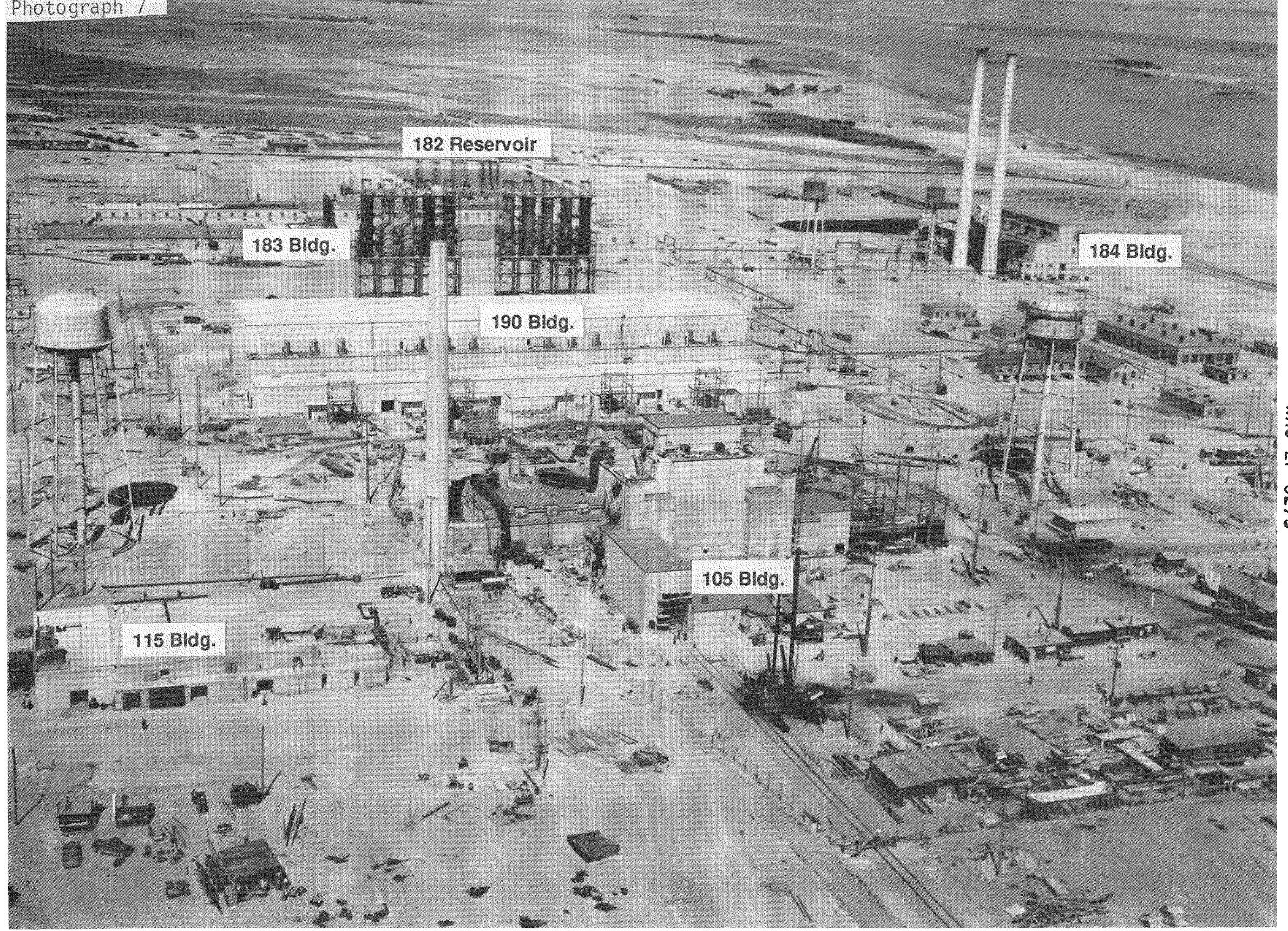




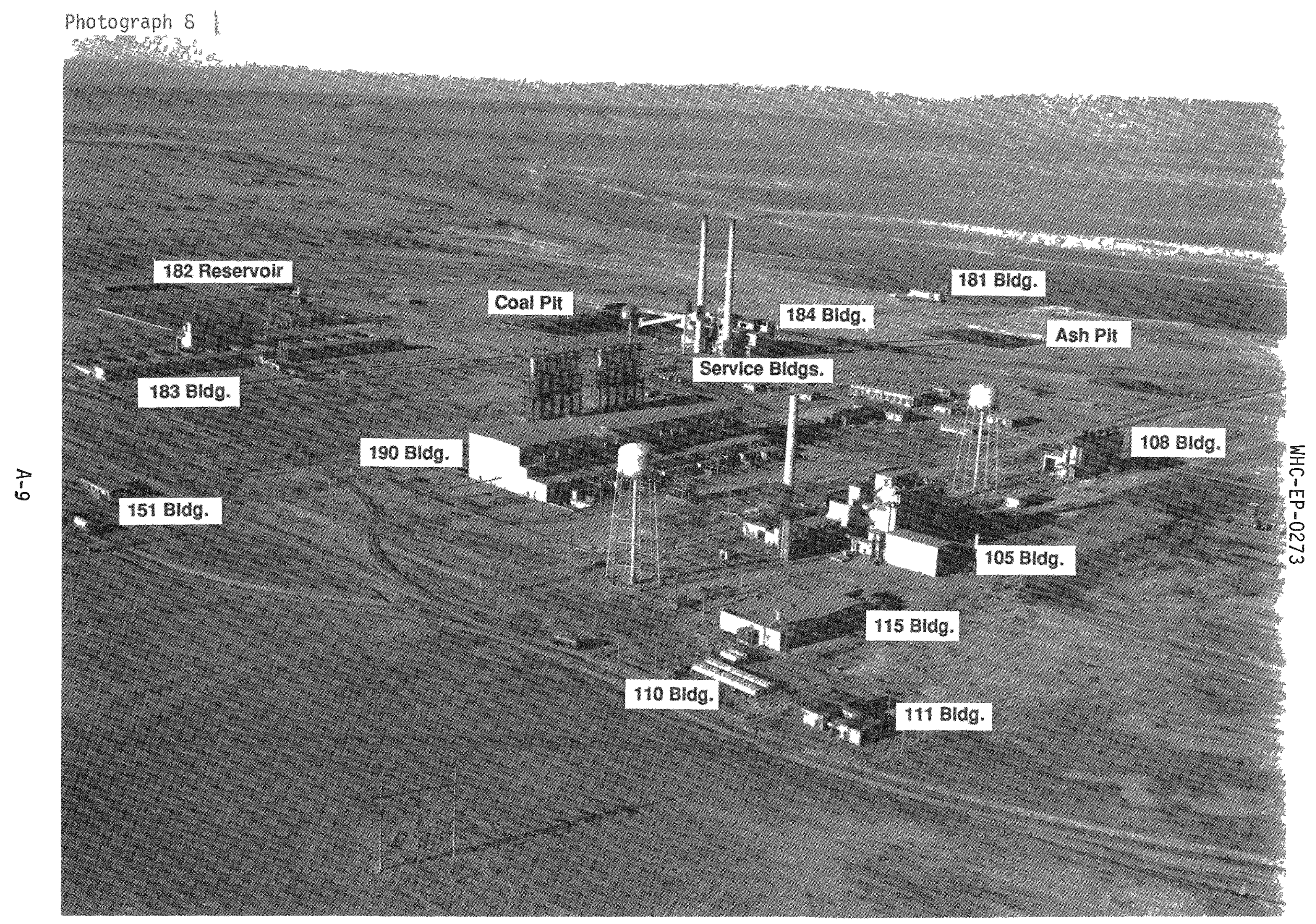

Construction was completed and 100-B Area was turned over to Operations on September 13, 1944. This photo shows $100-B$ as it appeared at the start of operations The photo is taken looking north. 
Photograph $S$

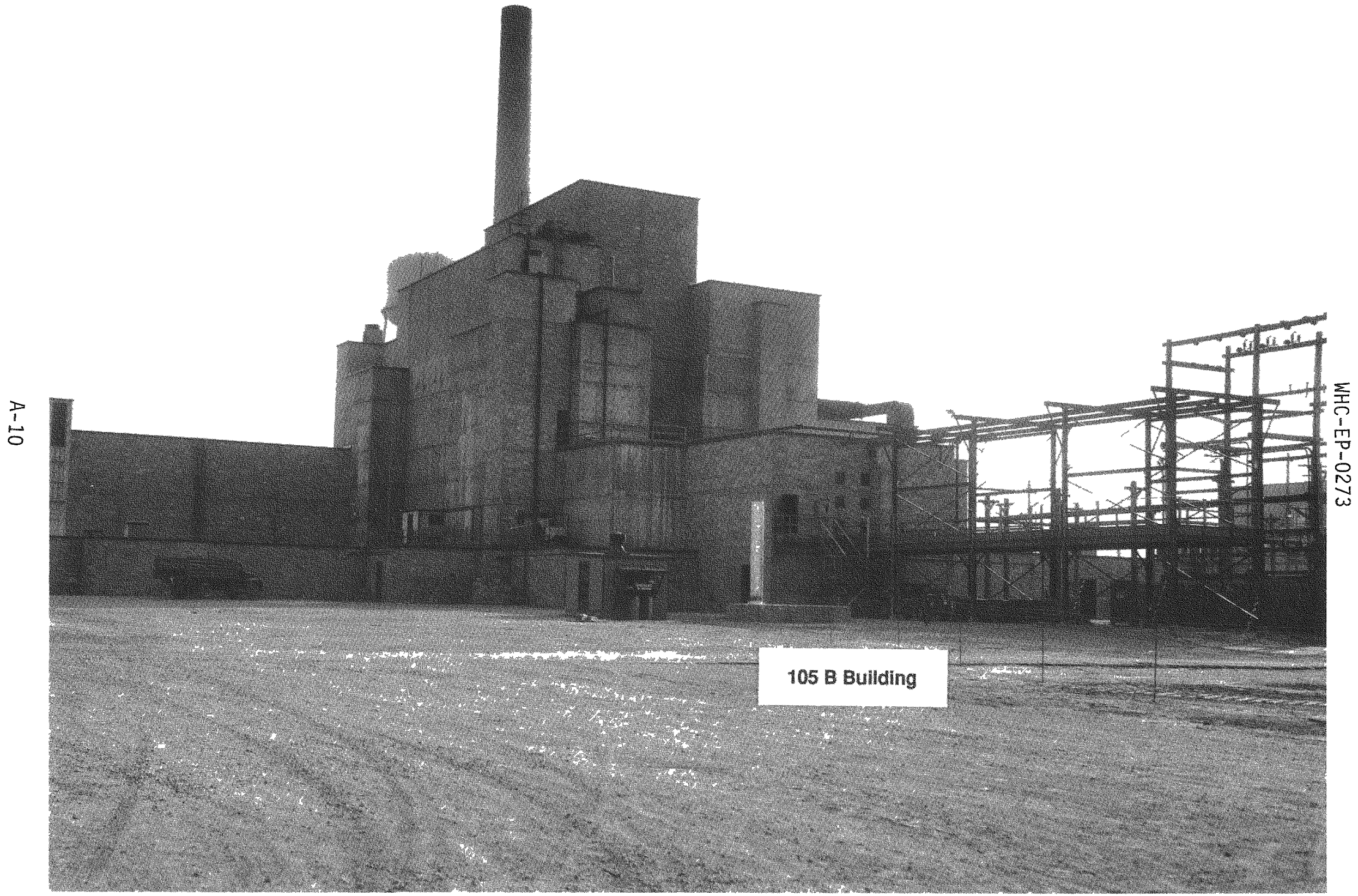

Consideration is being given to retaining 105-B Reactor Building as an historical site. This photograph shows the southeast side of the reactor building. 
This photograph and the two that follow indicate some of the complexities of the design and structure of the 105-B Reactor Building. These three photographs document the progress of construction up to the laying of the graphite moderator block.

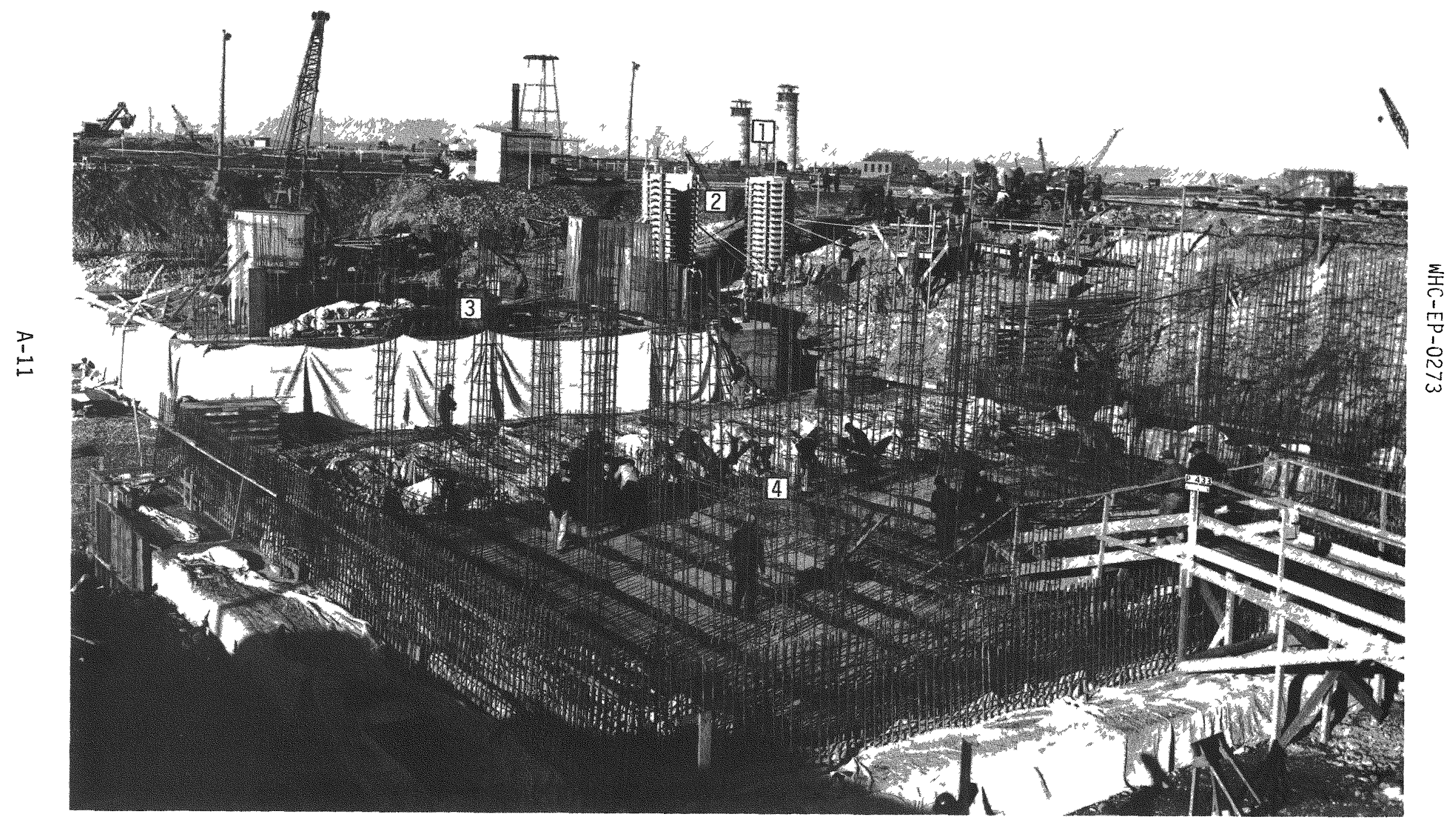

105-B Reactor Building

1. 184 Powerhouse Smoke Stacks

2. Horizontal Control Rod Hydrautic Accumulator Shafts
3. Reactor Base

4. Irradiated Fuel Storage Basin 


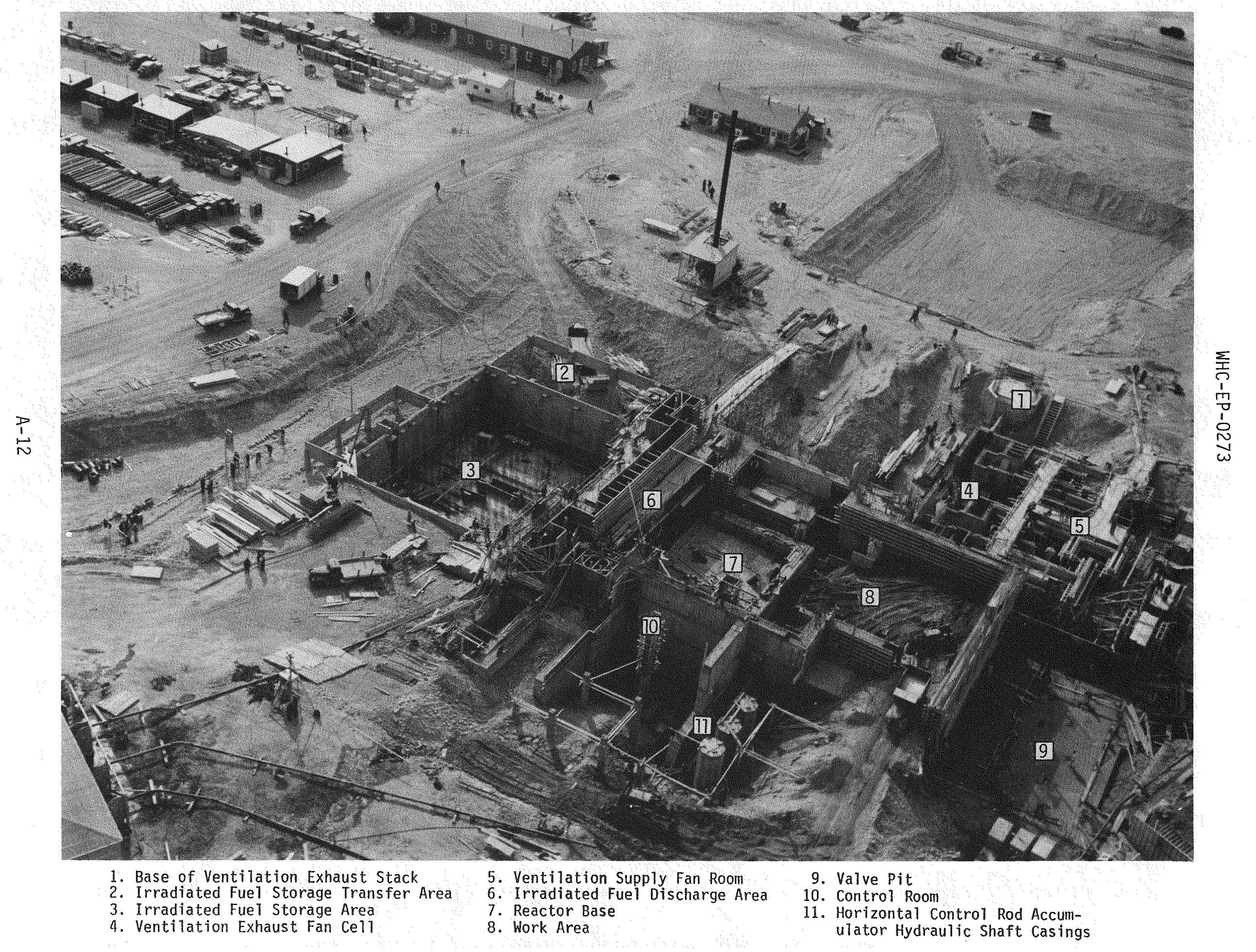




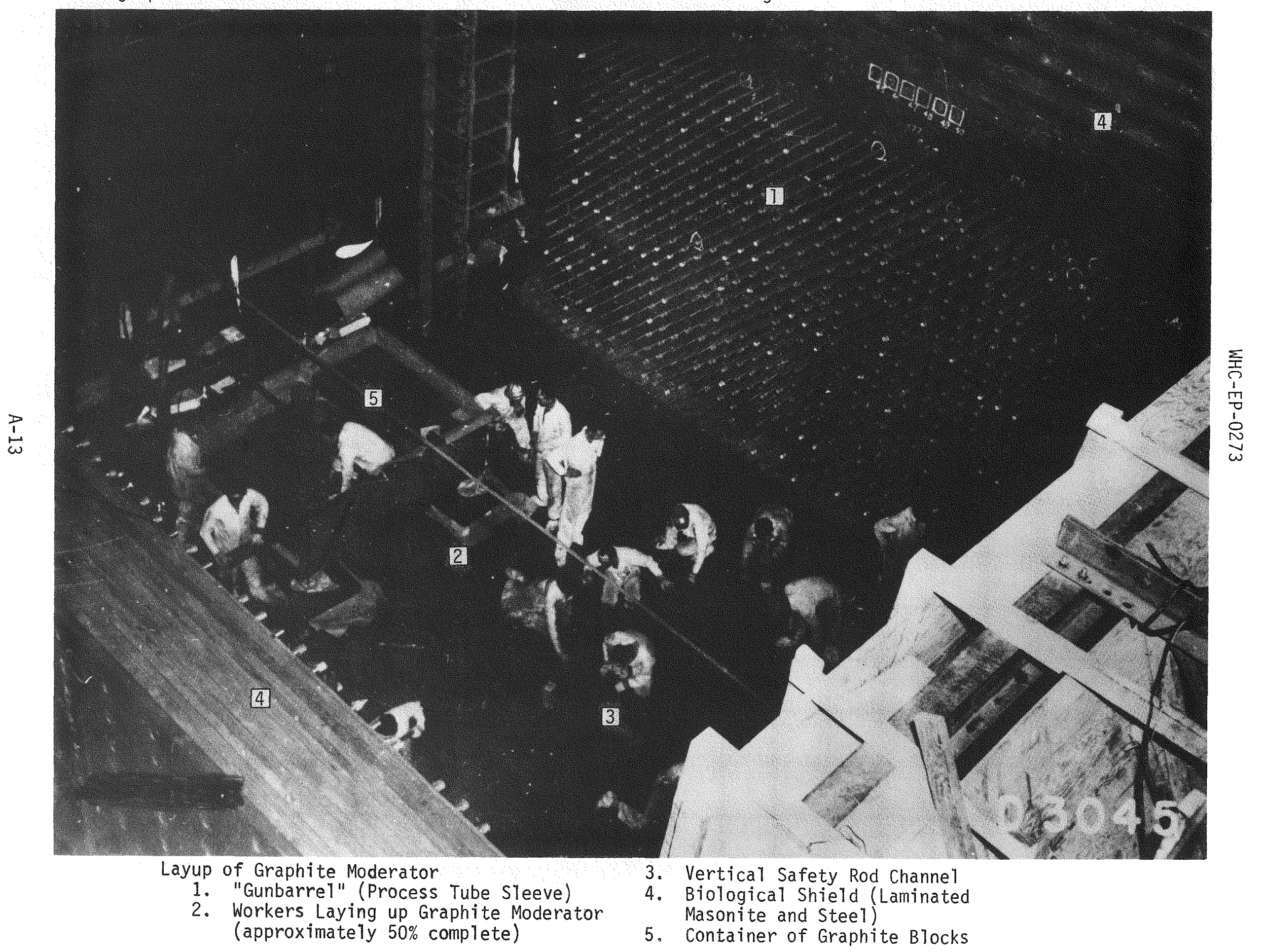




\section{DISTRIBUTION}

Number of copies

\section{3}

1

\section{1}

U.S. Department of EnergyRichland Operations office

K. E. Clark

A7 -27

R. D. Freeberg

A6- 95

J. D. Goodenough

A6-95

Pacific Northwest Laboratory

J. C. Chatters

K5-11

Westinghouse Hanford Company

W. F. Heine

R1 - 15

M. C. Hughes

$\mathrm{R} 1-15$

G. W. Jackson

$R 2-29$

R. E. Lerch

$\mathrm{H} 4-51$

G. A. Tarcza

A3-11

V. P. Treadway

B3 -27

R. K. Wahlen

A3 -30

W. P. Whiting

B3 -30

R. A. Winship

A3 -30

Publications Services L8-07

Central Files

L8-04

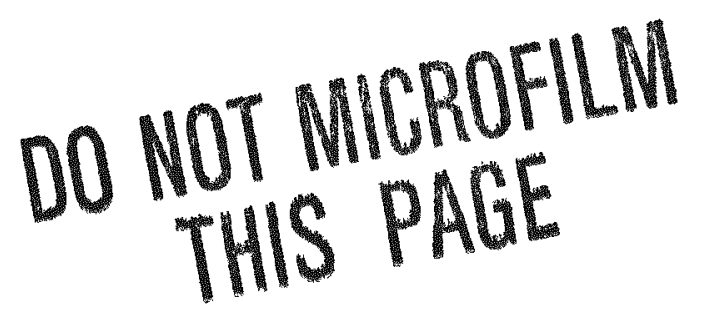


WHC-EP-0273

DO NOT WOSNOLN THIS PALE

AX 